Stockholm Faculty of Law

Research Paper Series

\title{
Regulating the new self- employed in the Uber economy: what role for EU competition law?
}

Victoria Daskalova 


\title{
Regulating the new self-employed in the Uber economy: what role for EU competition law?
}

\author{
By Victoria Daskalova*
}

\begin{abstract}
This paper discusses the role that EU competition law can play in regulating the 'new self-employed' precarious workers formally considered to be micro-enterprises. Specific attention is paid to the newest type of 'new self-employed', namely those engaged via matchmaking platforms arranging for work to be contracted 'on-demand'. Despite their unequal bargaining position, self-employed are barred from bargaining collectively due to the (EU) competition rules. The paper argues that the problem will not be solved by modifying the respective tests for 'worker' and 'undertaking' in EU law or by introducing exceptions under Article $101 \mathrm{TFEU}$. Then it adopts a regulatory approach to canvass the different legal instruments available to address exploitation concerns in the context of the Uber economy and discusses the role that EU competition law can play in such a regime.
\end{abstract}

\section{Keywords}

Sharing economy, self-employed, collective bargaining, cartel prohibition, abuse of dominant position, EU competition law

\section{Introducing the Uber economy}

What do a substitute orchestra musician from the Netherlands, a free-lance actor in Ireland, and Microsoft have in common? They have all been subject to competition law enforcement in the EU. Self-employed persons, which include independent contractors, freelancers and occasional substitutes, are considered undertakings and thus fall within the scope of the EU competition law. On the face of it, this is nothing new - independents such as doctors, lawyers, and self-employed entrepreneurs have long fallen within the scope of the competition rules and this arrangement has hardly been questioned. However, developments in labor markets have created a new class of selfemployed - the so called "the new self-employed" to which the competition rules increasingly apply. With the developments in ICT and business models - the boom of the "sharing" and "on demand" economy, the concept of "undertaking" now applies to individuals who seem to share more characteristics with precarious workers than with entrepreneurs. This requires taking a fresh look at the way competition law deals with its new subjects and, more broadly, the way this type of legal relationship is regulated.

The departure point for this paper is the fundamental problem justifying the existence of labor regulation - the fact that parties are not in an equal bargaining position and the risk of abuse of monopsony power. ${ }^{1}$ Historically, this problem has been solved by two means: the introduction of labor regulation (labor law) and the explicit permission for workers to bargain collectively. This solution, however, is being challenged by developments in business organization and technology. For the most

\footnotetext{
* The author is an Assistant Professor in Law, Governance and Technology at the University of Twente in the Netherlands. She can be reached at v.i.daskalova@utwente.nl.

${ }^{1}$ Manning, Monopsony in Motion: Imperfect Competition in Labor Markets (Princeton University Press, 2003).
} 
part of the twentieth century, this regulatory arrangement has covered most humans who sell their labor for a living. Business trends towards vertical disintegration ${ }^{2}$ and increasingly lengthy supply chains associated with globalization have increased the number of those selling their labor outside the traditional employment contract. The latest frontier is reached thanks to technology: it is increasingly possible to procure infinitesimally small quantities of labor 'on-demand' - via matchmaking platforms and crowdsourcing services.

Uber's name is most often associated with the so-called "sharing" or, as the European Commission puts it, "collaborative" economy; yet, Uber's success is representative of deeper changes in the marketplace for services, and increasingly, the market for labor. The advent of Uber is symbolic of a platform-based economy in which supply can be matched with demand instantaneously. In this new economy transactions can be cleared quickly thanks to online payment systems like Visa and MasterCard, and the quality can be monitored via user reviews. These changes have led to unprecedented possibilities for improving efficiency but also raise questions of worker exploitation. With fast and widespread Internet connections, a population armed with smartphones, and the availability of online payment processing systems, anyone can join the workforce almost instantaneously. Consumers can be matched online with fellow citizens for small offline jobs such as cleaning or a car ride. Whereas in the past such transactions might have fallen under the label "informal economy", they are increasingly formalized through the online platforms. With their formalization, it is also possible for companies to legally hire individuals - cheap workers for short periods of time, whose services are available "on demand". Of course, workers are available not only for "offline tasks" such as cleaning or driving, but also for tasks strictly completed online. The possibility to complete tasks by breaking them up and hiring people to do small bits of work for pay - "crowdwork" or "crowdsourcing" of which the Amazon Mechanical Turk platform is a prominent example ${ }^{3}$ - opens up unprecedented possibilities for companies to optimize their use of labor.

These developments have strained the traditional model of labor regulation which solved a problem of unequal power by creating the legal category of 'worker'. The question asked by labor lawyers is how labor law can adapt and respond to these challenges. Given that the laborers in question are independents, however, another question becomes relevant - what the role of commercial law, and in particular, the role of competition law is in solving or exacerbating the problem at hand. This paper argues that although competition law is often perceived as a challenge for labor rights, competition law can step in to fill the gaps in labor law. Thus, it argues that competition law can be one of the regulatory tools to address the problem of precarious independents.

This is indeed an interesting suggestion as competition law has mainly been applied to restrict the possibilities for self-employed to bargain collectively. A number of cases from national competition authorities imply that authorities perceive micro-cartels among self-employed as easy targets for enforcement action. Thus, in 2001 in Ireland, the competition authority decided that self-employed actors cannot set tariffs and contract terms collectively ${ }^{4}$ and in 2007, the Dutch Competition Authority issued a reflection document warning that setting of minimum tariffs by a union representing self-

\footnotetext{
${ }^{2}$ Collins, 'Independent Contractors and the Challenge of Vertical Disintegration to Employment Protection Law' (1990) 10 (3) Oxford Journal of Legal Studies, 353.

${ }^{3}$ Companies such as Amazon Mechanical Turk make it possible to complete tasks through "crowdwork", paying a number of people as little as 0.01 USD for a couple of minutes of labor such as tagging pictures or doing translations online.

${ }^{4}$ Decision No E/04/002 (Case COM/14/03) Agreements between Irish Actors' Equity SIPTU and the Institute of Advertising Practitioners in Ireland concerning the terms and conditions under which advertising agencies will hire actors.
} 
employed is contrary to competition law. ${ }^{5}$ The document - concerning collective bargaining covering self-employed orchestra musician substitutes - gave rise to a reference for a preliminary ruling to the Court of Justice. ${ }^{6}$ The implications of this judgment, in which the Court ruled that so called 'false selfemployed' are not to be considered undertakings for the purpose of competition rules, have been under-explored. More broadly, the appropriate approach of competition authorities toward collective agreements by self-employed has not been adequately addressed.

This paper aims to fill this gap in the literature by discussing the possibility for competition law to help solve the problem of unequal bargaining power of the new self-employed. The paper is structured as follows. Firstly, the new subjects of competition law are introduced. Social science literature research shows that there is a big difference between the traditional self-employed, ${ }^{7}$ and the so called 'new self-employed' who share more characteristics with precarious workers. Secondly, the paper considers the possibility of addressing the problem by revising the traditional definition of 'worker' with the EU law definition of worker as a case in point. The paper shows that unless the concept of worker is broadened beyond recognition, the newest self-employed will never qualify for status as 'worker'. Next, the paper considers the meaning of the concept of 'undertaking' under EU competition law and finds that the concept is very broad and limiting it to exclude workers from the scope is a challenging task. Having established the difficulty of solving the problem by adjusting the definitions, the paper proposes a regulatory approach to solving the problem of unequal bargaining power between selfemployed and their employers and discusses the role for competition law can play in designing a new regulatory regime.

\section{The newish subjects of EU competition law}

Freelancers have existed for ages - before there was labor law and before there was competition law. ${ }^{8}$ They have traditionally been considered as falling within the scope of the competition rules without there being any questions as to the reasonableness of this arrangement. ${ }^{9}$ For years, the European Commission has explicitly included self-employed in the category of 'micro-enterprises' in a variety of documents. ${ }^{10}$ So how come the question comes to the fore now? The answer is evident once we consider how the category of 'self-employed' has traditionally been defined and contrast this more traditional thinking with the way the 'population' of this category has increased and evolved.

\footnotetext{
${ }^{5}$ Dutch Competition Authority (Nederlandse Mededingingsautoriteit), Cao-tariefbepalingen voor zelfstandigen en de Mededingingswet: visiedocument (Collective labor agreements determining fees for self-employed and the competition law: a reflection document) (2007). ${ }^{6}$ Case C-413/13 FNV Kunsten Informatie en Media v Staat der Nederlanden [2014] ECLI:EU:C:2014:2411.

${ }^{7}$ As discussed below, the competition rules have always applied to self-employed; however, this has never caused much question or debate since these self-employed were perceived as genuine entrepreneurs.

${ }^{8}$ The etymology of the word "freelance" takes us back to the Middle Ages when it was used to refer to mercenary knights in possession of a horse and a lance, who would offer their services against payment to persons or states. See Oxford English Dictionary < http://www.oed.com/ >.

${ }^{9}$ See section 4 below which discusses the concept of 'undertaking' in EU competition law.

${ }^{10}$ See Commission Recommendation of 6 May 2003 concerning the definition of micro, small and medium-sized enterprises [2003] OJ L

124/36, Article 1 which provides the following definition of an enterprise: "An enterprise is considered to be any entity engaged in an economic activity, irrespective of its legal form. This includes, in particular, self-employed persons and family businesses engaged in craft or other activities, and partnerships or associations regularly engaged in an economic activity." Also in European Commission (DG Enterprise and Industry), "The new SME definition User guide and model declaration" (2005) available via the EU Bookshop and at <http://ec.europa.eu/enterprise/policies/sme/files/sme definition/sme user guide_en.pdf >, p.12.
} 
Much of the traditional way of thinking about self-employed has considered them to be entrepreneurs or petty bourgeois. ${ }^{11}$ In some professions, namely the so-called 'liberal professions' of medical doctors, lawyers, and accountants, self-employment has long been the standard. Similarly, no questions have been raised regarding the status of small-business owners such as independent shopkeepers, farmers, craftsmen and hairdressers. These types of self-employed continued to exist even when salaried employment became the norm in developed countries; however, the number of self-employed showed a steady decline in this category through the latter half of the twentieth century. ${ }^{12}$

Since the last decades of the twentieth century the trend of dwindling self-employment has been reversed. ${ }^{13}$ Presently, in the EU, we observe a growth in the number of self-employed. ${ }^{14}$ However, the increase reflects the rise of a new type of self-employed with those inflating the ranks being very different from the traditional self-employed in important ways. Most of them are so called 'solo' selfemployed which means they do not employ others. These 'new self-employed' as they came to be called in the social science literature ${ }^{15}$ are often much less independent and financially stable than the traditional self-employed. As summed by Buschoff and Schmidt in an often-cited contribution:

"The new self-employed do not correspond to the traditional profile of the entrepreneur, given that they work on their own account and without employees, often in professions with only low capital requirements. A growing share of these workers can be found on the one hand in 'modern' servicesector branches (such as education, health, financial and enterprise services) and on the other hand in the construction industry (via outsourcing and subcontracting). Such types of work are often located at the boundary between self-employment and dependent employment, but mostly they are formally defined as self-employment."16

The social science literature now commonly draws distinctions between self-employed in order to account for the radical differences between members of the category.

Another distinction drawn in social science is between 'voluntary' self-employed and 'involuntary' selfemployed: the former choose for this option in order to take advantage of better possibilities - be it higher profits or more flexibility in type of work and working hours; the latter aspire to employment but have been "pushed" into a self-employment because of crisis or necessity. ${ }^{17}$ Buschoff and Schmidt speak of "opportunity start-ups" and "necessity start-ups"; the former category covering classical entrepreneurs and those desiring greater autonomy, while the latter describing those pushed into selfemployment for lack of labor market opportunities. ${ }^{18}$ The concern is that the new self-employed are such not by choice and they are likely to be laboring in precarious conditions. Scholars argue that the "new self-employed" often face more risks than regular employees but without the protections

\footnotetext{
11 Jansen, 'Self-employment as Atypical or Autonomous Work: Diverging Effects on Political Orientations' (2016) 0(0) Socio-Economic Review, 1.

${ }^{12}$ Schulze Buschoff and C Schmidt, 'Adapting Labour Law and Social Security to the Needs of the "New Self-Employed" - Comparing the UK, Germany and the Netherlands' (2009) 19(2) Journal of European Social Policy, 147, 148.

13 Ibid., 148.

${ }^{14}$ A 2014 survey of 24 European countries shows that $14 \%$ of workers are self-employed. The highest numbers of self-employed are in Southern in Eastern European countries with $30 \%$ of the workforce in Greece being self-employed. However, numbers are rapidly rising in the Netherlands and the UK. See I Hatfield, 'Self-employment in Europe' (2015) Institute for Public Policy Research Report, 3 and figure 2.1. on 8. The report uses data from Eurostat.

${ }^{15}$ The term is often linked to the work of Buschoff and Schmidt op. cit. supra note 12.

16 Ibid.

${ }^{17}$ Dekker, 'Self-Employed without Employees: Managing Risks in Modern Capitalism' (2010) 38(4) Politics \& Policy, $765,768$.

${ }^{18}$ Buschoff and Schmidt op. cit. supra note 12, at 149.
} 
available to workers. ${ }^{19}$ According to Professor of social security law Mies Westerveld, "these workers fall through the cracks with regard to both protective labour laws and opportunity-creating business laws." 20

Unlike the traditional members of the category, the new self-employed do not aim to grow a business or employ others in the future; thus, they do not have the ambition to be 'entrepreneurs'. Thus, the established sociological understanding of self-employed as "a relatively homogenous social class with shared interests as entrepreneurs and (potential) employers" ${ }^{21}$ is no longer justified. Research shows that many self-employed today vote differently ${ }^{22}$ and support policies more closely aligned with the preferences of workers than of employers. ${ }^{23}$ These results stand in stark contrast to the common portrayal of self-employed which emphasizes their entrepreneurial independence and desire for business success, and lack of interest in a salaried position. Thus, perceiving self-employed as entrepreneurs or as 'would-be employers' for the purpose of regulation is problematic. This is especially true given that data shows that the majority of self-employed in the EU today are without personnel - they do not employ other workers and employership is not the norm. ${ }^{24}$ This reality stands puts in question the much praised autonomy and flexibility, creativity and innovativeness touted especially in the context of the sharing economy.

Linking the growth in the number of self-employed to the rise of the sharing economy would be an overstatement. Scholars trace the growth in the category of self-employed to a number of factors. The rise of the new self-employed seems to coincide with the trend in the beginning of the 1980s toward 'vertical disintegration' triggered by recession, a trend which reversed the dominant thinking throughout much of the $20^{\text {th }}$ century which emphasized vertical integration. ${ }^{25}$ Cost considerations, changing preferences of management, developments on financial markets, and a high level of unemployment are some of the reasons given for this changing trend. ${ }^{26}$ These developments have amounted to a trend in developed countries in which the distinction between employment and commercial activity is breaking down. ${ }^{27}$ However, international trade agreements related to services such as the General Agreement on Trade in Services (GATS) have also contributed to this trend. ${ }^{28}$ In the EU, provisions on free movement of services have allowed workers from jurisdictions with lower wages to move to higher-wage countries despite legal restrictions on labor markets. For instance, the $\mathrm{ECJ}$ judgment in Becu shows that whereas labor legislation requiring the use of certain dock workers cannot be viewed as a restriction of competition, it should nonetheless not prevent self-employed workers from providing cross-border services. ${ }^{29}$

\footnotetext{
19 lbid.

${ }^{20}$ Westerveld, 'The Stepchild of Labour Law: The Complex Relationship Between Independent Labour and Social Insurance (Inaugural lecture at the University of Amsterdam, 2 December 2011).

${ }^{21}$ Jansen op. cit. supra note 11.

${ }^{22} \mathrm{lbid}$.

${ }^{23}$ Dekker, op. cit. supra note 17.

${ }^{24}$ Jansen op. cit. supra note 11 at 4 and also figure 1. See also van Stel, Wennekers and Scholman, Solo Self-employed versus Employer Entrepreneurs: Determinants and macro-economic Effects in OECD Countries (2014) EIM Research Report.

${ }^{25}$ Collins op. cit. supra note 2 referring to GS Bain (ed), Industiral Relations in Brituain (Oxford 1983), 95-98.

${ }^{26}$ Collins op. cit. supra note 2 at 359-362.

${ }^{27}$ Fudge, 'Blurring Legal Boundaries: Regulating for Decent Work' in Fudge, McCrystal and Sankaran (eds), Challenging the Legal Boundaries of Work Regulation (Hart Publishing 2012), p. 10.

${ }^{28} \mathrm{Ibid}$., 13.

${ }^{29}$ Case C-398/95 SETTG v Ypourgos Ergasias [1997] ECLI:EU:C:1997:282 affirmed in C-22/98 Becu and Others [1999] ECLI:EU:C:1999:419, [36].
} 
This paper does not attempt to delve into the nuances of the distinctions among self-employed in the literature, ${ }^{30}$ but builds on the widely accepted distinction between 'traditional' self-employed and 'new self-employed' as identified by Buschoff and Schmidt, namely: working 'solo', being active in markets with low capital requirements, and mostly offering their labor in the form of services on the market. These self-employed are not real entrepreneurs and yet they do not meet the criteria for the legal status of 'worker'. Most definitions of 'worker' are based around concepts of control by primarily one client, integration within the hosts' organization and the risk allocation test. ${ }^{31}$ For the purpose of labor law and collective bargaining rights, they are not workers but micro-enterprises.

This development has been taking place for several decades now. Already in 1990, Hugh Collins spoke of 'a crisis in legal concepts' 32 with respect to the distinction between regular employees and independent contractors. Still, a solution has not been found and the law does not recognize the heterogeneity within the 'self-employed' category.

Before proceeding, it is important at this point to draw a further distinction. Much of the development in the growth of self-employed described above is subsumed under the term 'bogus' or 'false selfemployment'. However, the use of this term does not do justice to the developments taking place. Bogus self-employment is a problematic term because it is modelled after the legal definitions of 'worker', ${ }^{33}$ which, it is argued here, have become outdated in the context of labor market developments. As noted in a report prepared for the European Commission:

"Bogus self-employment can be defined as occurring when an individual is registered as being selfemployed, but is de facto bound by an employment relationship." 34

Because bogus self-employment is defined as 'misclassification of workers' 35 the implication is that were it not for the formal legal status, the worker would meet the criteria for worker. Thus, the term fails to fully capture the developments taking place on labor markets. Certainly, many of those formally classified as 'self-employed' are 'bogus self-employed'; yet, beyond those there are the many selfemployed who are precarious just like workers but who fail to meet the criteria for 'worker'. Bogus self-employment thus refers to fraudulent situations which a judge could 'unmask'. However, the new self-employed encompass also those whose objective employment situation is such that they stand no chance of proving a 'worker' status in court. Thus, the new self-employed is a phenomenon which is not necessarily a reflection of an enforcement gap; rather, it is a gap that arises when the legal definitions drift away from reality.

\footnotetext{
${ }^{30}$ Labor law professor Judy Fudge proposes three distinctions: firstly, self-employed who are knowledge workers, who have an education and access to social and economic capital and do not need labor protection; secondly, freelancers who have some control and possess some human, social and economic capital, but who may be susceptible to exploitation; and thirdly, the most precarious self-employed who draw from 'vulnerable social locations' and who are often women, ethnic minorities, or undocumented migrant workers. Fudge op. cit. supra note 27 at 12-13. Yet, even for knowledge workers there is no guarantee that they will remain immune to exploitation as their position depends on whether they are in demand or whether there is an oversupply of them. See Fudge op. cit. supra note 27 , footnote 59 on page 12.

${ }^{31}$ Here I draw on the work of Collins op. cit. supra note 2, 369-376. This point is further argued in section 3 below in which the EU law concept of 'worker' is discussed.

32 Ibid., 369.

${ }^{33}$ The European Commission speaks of 'persons posing falsely as self-employed workers to circumvent national law' in European Commission, Green Paper on Modernising labour law to meet the challenges of the 21st century [2006] COM(2006) 708 final, 11. ${ }^{34}$ O'Brien, Spaventa, and de Coninck (FreSsco network), Comparative Report 2015 - The Concept of worker under Article 45 TFEU and certain non-standard forms of employment, (Report prepared for the European Commission, April 2016) , 49 and Jorens, Gillis, Valcke \& De Coninck, 'Atypical Forms of Employment in the Aviation Sector', European Social Dialogue, European Commission, 2015.

35 Ibid., at 10 and 46.
} 
This paper argues that the need for solutions is even more pressing given that the gap is widening. The latest developments in labor markets are made possible by technology advances and globalization: the surge in 'on-demand' labor, 'just-in-time' labor, crowdwork, and the sharing economy. ${ }^{36}$ This change presents the ultimate challenge for concepts of 'worker' based on repeated work under the control of a particular employer. This is a truly novel development which represents possibilities unimaginable a couple of decades ago and serves to stretch the category of 'self-employed' even further. In fact, these developments may well have created what one might call 'the newest self-employed'. The novelty of the latest development is best summed up by the CEO of CrowdFlower, a crowd-working service:

"Before the Internet, it would be really difficult to find someone, sit them down for ten minutes and get them to work for you, and then fire them after those ten minutes. But with technology, you can actually find them, pay them the tiny amount of money, and then get rid of them when you don't need them anymore. ${ }^{137}$

Nowadays, services such as the Amazon Mechanical Turk allow for just that: the possibility to purchase labor remotely, for a very short period of time. In the case of Amazon's Mechanical Turk, independent service providers perform small tasks or fragments of tasks - such as tagging photographs, proofreading, or processing data. Because the tasks can be broken up into small pieces, the work can be outsourced to many independents. The platform 'matches' service-providers and clients and processes payment. Just like in the case of Uber, the service provided is 'match-making' between two independent parties, not employment. This type of work - fragmented, short-term in nature, done at the independent's discretion, for multiple clients - eschews traditional definitions of an employment relationship. Yet, it gives rise to precisely the type of problem that labor laws and the right to collective bargaining were meant to correct for - the potential for exploitation in the context of unequal bargaining power between two contracting partners.

\section{The new self-employed: a problem for labor law or a problem for competition law?}

The section above has shown that the category of "self-employment" is no longer reserved for the traditional bourgeois or the innovative entrepreneur. Increasingly, this label is attached to independents laboring in very precarious conditions; and while the possibility to hire workers 'ondemand' has been seen as expanding opportunities for participation in the economy and access to labor markets, ${ }^{38}$ so has it also been associated with erosion of standards of labor protection and the normalization of precariousness. ${ }^{39} \mathrm{~A}$ number of labor law scholars have commented on these developments, in particular the sharing economy and the on-demand economy and argued for change.

\footnotetext{
${ }^{36}$ De Stefano, "The Rise of the "Just-In-Time Workforce": On-Demand Work, Crowdwork and Labour Protection in the "Gig-Economy" in International Labour Office, Inclusive Labour Markets, Labour Relations and Working Conditions Branch (Geneva: ILO, 2016 Conditions of work and employment series, No. 71).

${ }^{37}$ As quoted in Marvit, 'How Crowdworkers Became the Ghosts in the Digital Machine' (5.02.2014, The Nation) .

${ }^{38}$ European Commission, 'A European agenda for the collaborative economy' (Communication) COM (2016) 356 final.

${ }^{39}$ Aloisi, 'Commoditized Workers: Case Study Research on Labor Law Issues Arising from A Set of

“On-Demand/Gig Economy” Platforms' (2016) 37(3) Comparative Labor Law \& Policy Journal, 653.
} 
${ }^{40}$ There is currently much debate as to what the core concept of a worker entails. ${ }^{41}$ In particular, the argument is for change in legal categories and concepts and re-defining the definition of worker in order to reflect the changes in society. ${ }^{42}$ By contrast, competition law scholars have largely been silent on the issue of the rise of sharing platforms and their contractual relations with the independents physically carrying out the services they mediate. ${ }^{43}$

The obvious clash of competition law and labor law lies in the approach to collective bargaining agreements. This becomes evident as those engaged in the sharing economy increasingly demand rights and try to organize. ${ }^{44}$ Can they do so legally? In the context of these questions, the distinction drawn between 'worker' and 'undertaking' becomes important. Thus, the definition of worker is important not only to preserve rights under labor law but to prevent the application of commercial laws meant to regulate business behavior. Competition laws in various jurisdictions throughout the world have been increasingly applied to collective bargaining agreement efforts of self-employed without personnel - be they engaged via online platforms in the context of the sharing economy or self-employed in other contexts. ${ }^{45}$

The issue of collective bargaining - setting of prices, minimum contractual safeguards - is probably the area in which we observe the most obvious divergence between labor law and competition law. Collective bargaining for workers is considered a fundamental right, often protected in national constitutions, but also under EU law and international law. ${ }^{46} \mathrm{It}$ is considered a human right as evidence from its presence in sources such as the Universal Declaration on Human Rights, ${ }^{47}$ the International Covenant on Social, Economic and Cultural Rights, ${ }^{48}$ the European Social Charter and in the European Convention of Human Rights; ${ }^{49}$ it is enshrined in the International Labor Organization (ILO) constitution

\footnotetext{
${ }^{40} \mathrm{Ibid}$.; De Stefano, 'Non-Standard Workers and Freedom of Association: A Critical Analysis of Restrictions to Collective Rights from A Human Rights Perspective' (2015) Working Paper CSDLE “Massimo D’Antona” INT-123/2015, 1 and De Stefano (2016) op. cit. supra note 36; Rogers, 'Employment Rights in the Platform Economy: Getting Back to Basics' (2016) 10 Harvard Law \& Policy Review, 479; TodoliSignes, “Uber economy": employee, self-employed or the need for special employment regulation?' (2015) SSRN Working Paper <https://papers.ssrn.com/sol3/papers.cfm?abstract id=2703057>.
}

${ }^{41}$ Different approaches are possible to define what constitutes a worker. Relevant questions include the notion of control - to what extent does the company control or is able to control the worker, the imbalance of power in the relationship between employer and employee, the extent of integration in the organization in the sense of bearing own commercial risk or not, the availability of entrepreneurial opportunities, the ownership of the tools necessary for production. For a detailed discussion from a US perspective, see Rogers op. cit. supra note 40 at 479-520. See also De Stefano (2016) op. cit. supra note 40 at 6-10 and Davidov, 'Freelancers: An Intermediate Group in Labour Law?' in Fudge, McCrystal and Sankaran (eds), Challenging the Legal Boundaries of Work Regulation (Hart Publishing 2012).

42 Already in 1990, Hugh Collins spoke of a 'crisis in legal concepts', op. cit. supra note 2 at 369.

${ }^{43}$ Nowag, 'The UBER-Cartel? UBER between Labour and Competition Law' (2016) 3 Lund Student EU Law Review, 95.

${ }^{44}$ Chen, "An Uber Labor Movement Born In a Laguardia Parking Lot" (8.02.2016., The New Yorker);

'UK - Deliveroo workers seek workers' rights and union recognition' (8.11.2016, Staffing Industry Analysts) < http://www2.staffingindustry.com/eng/Editorial/Daily-News/UK-Deliveroo-workers-seek-workers-rights-and-union-recognition-39984>. ${ }^{45}$ Fudge, McCrystal and Sankaran (eds), Challenging the Legal Boundaries of Work Regulation (Hart Publishing, 2012), especially Chapter 8 by Shae McCrystal. See also Buescher, 'FedEx Home Delivery v. NLRB, Another Example of Why We Need to Take a Fresh Look at the Common Law Test for Independent Contractor Status' (2010) ABA Labor Law Meeting; Rubiano, 'Precarious work and access to collective bargaining: What are the legal obstacles?' International Journal of Labour Research (2013) 5 (1), 133, 144. The author notes that in recent years competition authorities have actively targeted collective bargaining agreements covering the self-employed, and lists the Netherlands, and Denmark.

\footnotetext{
${ }^{46}$ Veneziani, 'Right of collective bargaining and action (Article 28)' in B Bercusson (ed), European Labour Law and the EU Charter of Fundamental Rights (ETUI, Brussels 2002), at 56. The author notes that many national constitutions contain the right to collective bargaining and some provide an obligation for negotiation on specific issues with given regularity.

${ }^{47}$ Article 23.4. of the Universal Declaration on Human Rights.

${ }^{48}$ Article 8 of the ICESCR protects the right to collective bargaining and industrial action.

${ }^{49}$ Article 11 European Convention on Human Rights.
} 
and various instruments to which many EU Member States are party ${ }^{50}$. In the EU, this right is protected in Article 28 of the Charter of Fundamental Rights of the European Union, which became binding with the entry into force of the Lisbon Treaty.

At the same time, the collective setting of prices and contract terms - cartelization - is one of the most egregious offences of the competition rules. Cartels are universally acknowledged as diminishing welfare and efficiency and promoting the private interests of the parties concluding them at the expense of welfare in society, in particular final consumers. In the context of labor, collective bargaining agreements are accepted despite the fact that they do represent a restriction of competition among workers ${ }^{51}$ and despite the fact that they can lead to higher consumer prices ${ }^{52}$. By contrast no such exception exists for companies, be they one-person enterprises or giants like Microsoft.

Thus, the legal distinction between worker and undertaking implies radically different consequences: under labor law, collective bargaining is the exercise of a fundamental right; under competition law it implies not only administrative but also civil liability, ${ }^{53}$ and depending on the jurisdiction - possibly also criminal liability. The distinction between "worker" and "undertaking" is thus of crucial importance for this issue.

For the EU Member States, the EU law interpretation of these concepts is vital. Firstly, EU law has autonomous definitions both for "worker" and for "undertaking". ${ }^{54}$ This means they are not linked to definitions in national law but have an independent meaning in EU law and for the purpose of applying EU law. Furthermore, both definitions claim to be functional rather than formalistic. This means that the Court looks at the actual situation at hand rather than the legal form. These two notions go hand in hand. For instance, the Court has held that a person considered self-employed for the purposes of national law can be considered a worker for the purposes of EU law; ${ }^{55}$ in fact, as long as the person meets the EU law criteria for employment, her status is not affected by whether she is considered selfemployed in the national system for tax, administrative or organizational reasons. ${ }^{56}$ Similarly in the field of competition law, the Court has interpreted the term "undertaking" to meaning that the emphasis is on the activities the undertaking is engaged in as opposed to the legal status within the domestic legal system or the way in which the undertaking is financed. ${ }^{57}$

Furthermore, the reach of EU definitions can extend beyond EU law strictu senso. This is especially true for EU competition law. As the Court has held, the interpretation of EU law concepts matters even for "purely internal situations" when the provisions in questions are also applied in the same way for EU

\footnotetext{
${ }^{50}$ Especially important are ILO Convention No 87 on the Freedom of Association and Protection of the Right to Organise Convention and ILO Convention No 98 on the Right to Organise and Collective Bargaining.

${ }^{51}$ As decided in Case C-67/96 Albany International BV v Stichting Bedrijfspensioenfonds Textielindustrie [1999] ECLI:EU:C:1999:430.

52 Higher wages for workers would translate in higher prices or lesser quantities of the products produced by firms, thus negatively impacting the welfare of consumers.

${ }^{53}$ See Directive 2014/104/EU of the European Parliament and of the Council of 26 November 2014 on certain rules governing actions for damages under national law for infringements of the competition law provisions of the Member States and of the European Union [2014] OJ L 349 and C-453/99 Courage Ltd v Bernard Crehan and Bernard Crehan v Courage Ltd and Others [2001] ECLI:EU:C:2001:465.

${ }^{54}$ In the case of the term worker, the Court has held that ever since Case 75/63 Hoekstra v Bestuur der Bedrijfsvereniging voor Detailhandel en Ambachten [1964] ECLI:EU:C:1964:19; with respect to the notion of undertaking, since Case C-41/90 Klaus Höfner and Fritz Elser v Macrotron GmbH [1991] ECLI:EU:C:1991:161.

${ }^{55}$ Case C-256/01 Debra Allonby v Accrington \& Rossendale College [2004] ECLI:EU:C:2004:18, [7], confirmed in Case C-413/13 FNV Kunsten Informatie en Media v Staat der Nederlanden [2014] ECLI:EU:C:2014:2411, [35]

${ }^{56}$ Case C-256/01 Allonby, [72] confirmed in Case C-413/13 FNV Kiem, [36].

${ }^{57}$ This notion of undertaking was first established in Case C-41/90 Höfner and Elser and has been upheld ever since.
} 
law. ${ }^{58}$ Thus, EU interpretations of the concept of "undertaking" extend their reach beyond the application of EU law and affect the interpretation of the concept of "undertaking" in national law. This means that for the purposes of applying EU law, the categorization under national labor law is not relevant. The definition of "undertaking" and "worker" for the purposes of EU law, including the charter, is a matter of EU law, ultimately determined by the EU courts. This is one important constraint for national lawmakers. For instance, the Irish parliament has voted on an amendment to its competition law for the purpose of allowing self-employed to engage in collective bargaining; yet, the Attorney General and the European Commission have warned that such an amendment would run counter to the EU competition rules. ${ }^{59}$

In the absence of legal clarity, these matters are increasingly taken up to the Courts. Widely covered are the cases of Uber and Lyft drivers contesting their employment status in courts in the US and in the UK. ${ }^{60}$ Yet, the question extends to many other self-employed, not necessarily those employed by Uber but also those employed for 'on-demand' services - be they online or offline. Thus, the status of independent couriers and package deliverers has been contested - both in the UK and in the US. ${ }^{61}$

This section makes the argument that given the fundamental changes brought about by technology and globalization, no possible definition of "worker" will exempt the many independents caught in a precarious labor situation from the application of competition law. In the case of EU law, it argues that the interpretation of worker is rather narrow, whereas the interpretation of the concept of undertaking is broad. It also considers the implications of the judgment in the FNV Kiem case and concludes that even if it might be considered an exception, its scope is very narrow. In light of this, the following picture emerges: either the definition of 'worker' needs to be broadened in order to accommodate precarious workers or the approach under competition law needs to be adjusted. The conclusion reached is that in order to cover the most precarious workers engaged in the Uber economy on an "on-demand" basis, the definition of 'worker' would have to be stretched beyond recognition, to the point where it loses its core. Given the unattractiveness of this option, the paper proceeds to examine the possibilities for better protection of the most vulnerable independents under competition law.

\section{1. "Worker" versus "undertaking": narrow versus broad}

EU law upholds a clear separation between the categories 'worker' and 'undertaking. The case law is explicit that workers are not to be considered undertakings and thus do not fall within

\footnotetext{
${ }^{58}$ Case C-413/13 FNV Kiem, [18]. See also [19] in which the Court took into account the fact that in adopting the national provisions on competition, the Netherlands legislature explicitly aimed to harmonize its legislation with the European one. See also Case C-32/11 Allianz Hungária Biztositó and Others, EU:C:2013:160,[20].

${ }^{59}$ See Seanad Debates of $6^{\text {th }}$ July 2016, statement by Minister for Jobs, Enterprise and Innovation, Ms. Mary Mitchell O'Connor: ' The Attorney General believes the Bill, as drafted, appears to infringe Article 101 of the EU treaty. The European Commission considers that the Bill, as drafted, runs counter to EU competition law. It also believes the proposed exemptions appear very questionable in view of the longterm interest in ensuring efficient use of public budgets. The Government believes section 3, as drafted, goes far beyond the stated policy objective of the Bill of protecting vulnerable self-employed workers. Accordingly, it is the Government's intention to introduce an amendment to this section on Report Stage.' A full transcript is available via the Irish Parliament website $<\underline{\langle t t p: / / o i r e a c h t a s d e b a t e s . o i r e a c h t a s . i e />}$.

${ }^{60}$ Lien, 'Lyft settles worker misclassification lawsuit for \$12.25 million' (Los Angeles Times, 27.01.2016); Isaac, 'Judge Overturns Uber's Settlement With Drivers' (18.08.2016); However, a London employment tribunal found Uber drivers to meet the criteria for 'worker'. See Case Numbers: 2202551/2015 \& Others Mr Y Aslam, Mr J Farrar and Others -V- Uber [2016]. The London employment tribunal judgment is currently under appeal.

${ }^{61}$ FedEx Home Delivery v. NLRB 563 F.3d 492 (D.C. Circuit 2009). In the UK, the most recent action concerns a lawsuit filed by Deliveroo courriers 'UK - Deliveroo workers seek workers' rights and union recognition' (8.11.2016, Staffing Industry Analysts) < http://www2.staffingindustry.com/eng/Editorial/Daily-News/UK-Deliveroo-workers-seek-workers-rights-and-union-recognition-39984>.
} 
the scope of the antitrust rules. ${ }^{62}$ In practice, the status of independent service-providers is often unclear. The question thus arises how can we distinguish genuine undertakings and those who could fulfill the conditions to qualify as a worker? On several occasions, the Court has tried to elaborate on criteria to differentiate workers from self-employed - inter alia, for the purposes of applying the freedom of establishment provisions in an accession treaty, ${ }^{63}$ for the purpose of non-discrimination provisions of EU law, ${ }^{64}$ and for the purpose of competition law ${ }^{65}$.

Although the definition of worker varies depending on the area of EU law, ${ }^{66}$ the Court has been remarkably consistent regarding the core definition of what an employment relationship entails. The Court has held that "it is settled case-law that the essential feature of that relationship is that for a certain period of time one person performs services for and under the direction of another person in return for which he receives remuneration. ${ }^{\prime 67}$ This test is based on criteria that labor lawyers are familiar with - namely, subordination, commercial independence, and the stable nature of the employment relationship. The following section will examine these criteria and check to what extent they will be met by a worker engaged in the Uber economy - be it an Uber driver, or an 'on-demand' crowdworker. The conclusion is that traditional labor law testing criteria fail to capture this new breed of worker - the precarious on-demand self-employed.

\subsection{The subordination requirement}

One of the key factors in testing for employment - in the EU or elsewhere - is the subordination requirement. This requirement is sometimes known as a "control test" and is one of the recognized criteria of testing for the existence of an employment relationship in the labor laws of different jurisdictions. ${ }^{68}$ This test seems to be very much based on the traditional concept of a worker evident already in the AG Jacobs' opinion in the Albany case:

"Dependent labour is by its very nature the opposite of the independent exercise of an economic or commercial activity. Employees normally do not bear the direct commercial risk of a given transaction. They are subject to the orders of their employer. They do not offer services to different clients, but work for a single employer. For those reasons there is a significant functional difference between an employee and an undertaking providing services. That difference is reflected in their distinct legal status in various areas of Community... or national law. ${ }^{\prime 69}$

Under traditional employment, this requirement seems to be a sensible one. The employer controls the labor process by specifying what kind of work needs to be done, how it is to be done, with what materials, when and where. The employer is consequently the one who bears the risk - be it financial, commercial, or liability. However, this understanding fails to take into account the changing nature of

\footnotetext{
${ }^{62}$ Case C-22/98 Becu and Others [1999] ECLI:EU:C:1999:419.

${ }^{63}$ Case C-268/99 Jany and Others [2001] ECLI:EU:C:2001:616.

${ }^{64}$ Case C-256/01 Allonby.

${ }^{65}$ C-22/98 Becu and Others [1999] ECLI:EU:C:1999:419; Case C-309/99 Wouters and others [2002] ECLI:EU:C:2002:98; Case C-413/13 FNV Kiem.

${ }^{66}$ Case C-85/96 Martínez Sala [1998] ECLI:EU:C:1998:217, [ 31]. In this case the Court held that the definition of worker for the purposes of ex. Art. $48 \mathrm{EC}$ (free movement of workers) could differ from the definition of "worker" for the purpose of ex. Art $51 \mathrm{EC}$ (regarding powers of the Council to adopt measures related to social security of workers).

${ }^{67}$ Case C-413/13 FNV Kiem, para. 34.

${ }^{68}$ Collins op. cit. supra note 2, at 369. Rogers, op. cit. supra note 40.

${ }^{69}$ Case C-67/96 Albany International BV v Stichting Bedrijfspensioenfonds Textielindustrie [1999] Opinion of Advocate General Jacobs [1999] ECLI:EU:C:1999:28, [215].
} 
both salaried work and self-employment. According to Busschof and Schmidt, we observe a trend in which "dependent employment is increasingly associated with self-governed and autonomous work organization [...], while some types of work that are classified as self-employment are characterized by a reduction in entrepreneurial freedom as regards the provision of a service or by economic dependence on a single principal.." ${ }^{70}$ Thus, independents are not necessarily entrepreneurial; on the other hand, dependent workers often exhibit a lot of freedom and independence.

In light of the changing nature of work, the criterion is even more vague and susceptible to diverging interpretations. The Court's case law does not allow for a precise pinpointing of the concept of subordination. For example, in Allonby, a case concerning a self-employed school teacher who was previously employed as a teacher by the same college but was re-hired as an independent after her contract was terminated, the Court noted:

"[I]t is necessary in particular to consider the extent of any limitation on their freedom to choose their timetable, and the place and content of their work. The fact that no obligation is imposed on them to accept an assignment is of no consequence in that context." ${ }^{\prime 71}$

Similarly, in its judgment in FNV Kiem, discussed below, the Court held that what mattered for substitute musicians was "in particular, that their relationship with the orchestra concerned is not one of subordination during the contractual relationship, so that they enjoy more independence and flexibility than employees who perform the same activity, as regards the determination of the working hours, the place and manner of performing the tasks assigned, in other words, the rehearsals and concerts." ${ }^{72}$ Thus, on the face of it, there seems to be consistency in the Court's judgments and the criterion seems a sensible part of a test.

In a contemporary context, this prong of the test, however, has loopholes and is open to abuse. The example of scheduling flexibility quickly reveals the shortcomings of this criterion. Ironically, in FNV Kiem the Court of Justice did not consider that self-employed substitute musicians were deprived of flexibility and thus, there was no question that they were to be considered self-employed. At the same time, one can easily wonder whether a self-employed musician does in fact have a choice of when, where and how to play with an orchestra. The judgment went against expectations that a selfemployed musician who has to play with the orchestra at the given time and place has limited flexibility, that a construction worker who has to perform the work on the designated site in collaboration with others would have limited flexibility, and that bus drivers who are expected to respect a certain schedule would have limited flexibility. ${ }^{73}$

Furthermore, flexibility might be restricted in practice, yet difficult to prove in court. Media reports confirm that whereas some of those engaged in on-demand work via applications such as Uber and Handy do this on an occasional basis, many regard this as a full time job. Media also explains covert ways in which inflexibility is enforced. Accounts of self-employed providing services through companies such as Hermes, ${ }^{74}$ or Handy make clear that workers have shifts and that they can be

\footnotetext{
70 Buschoff and Schmidt, op. cit. supra note 12 at 150.

${ }^{71}$ Case C-256/01 Allonby. [72].

72 Case C-413/13 FNV Kiem, [37].

73 Pennings, 'Exceptie van de mededingingsbepalingen voor (schijn)zelfstandigen: de zaak FNV Kiem' [2015] 4 Nederlands tijdschrift voor

Europees recht, 111, 116

${ }^{74}$ Booth, 'There's no compassion': Hermes cut driver's work as wife was dying. Peter Jamieson asked to switch delivery days to take his wife to hospital, but says company refused, then withdrew his work" The Guardian (11.09.2016) <https://www.theguardian.com/uknews/2016/sep/11/hermes-driver-lost-rounds-asking-swap-days.> According to the driver, contractor Hermes refused to give him future assignments because he did not fulfill the shifts he was assigned.
} 
penalized for failing to take assignments or to fill shifts. ${ }^{75}$ There can be more subtle ways in which inflexibility creeps up - e.g. via user ratings. In the case of Uber, drivers have expressed worry that if they decide not to take a ride booked through Uber, their Uber rating would be affected thus negatively impacting the ability to perform work for Uber in the future. ${ }^{76}$ The company need not explicitly enforce minimum working hours or shifts; more nuanced practices such as indirect punishment via user ratings might mean that the driver's flexibility is de facto restricted.

Companies careful to avoid potential liability may adopt contractual approaches or rely on technology to avoid the appearance of fixed schedules or to place caps on the amount of work performed. Such compliance mechanisms could be automatically enforced - e.g. by blocking the account of a user after a certain time has been spent on the platform or by making the platform available to the freelancer for a fixed amount of hours per day. Platform operators may take measures to warn corporate users of the danger of repeated interaction with the same freelancer. It is worth considering the disclaimer on the Amazon Mechanical Turk website:

"[y]ou acknowledge that, while Providers are agreeing to perform Services for you as independent contractors and not employees, repeated and frequent performance of Services by the same Provider on your behalf could result in reclassification of that employment status." 77

In its Communication on the collaborative economy, the Commission reaches the conclusion that most independents engaged via sharing platforms will fail to meet the criteria of a worker. The Commission notes that for the subordination criterion to be met, "the service provider must act under the direction of the collaborative platform, the latter determining the choice of the activity, remuneration and working conditions." ${ }^{18}$ The Commission's analysis suggests that the subordination criterion is fulfilled when the platform will restrict the provider's choice of services to be provided, and direct how and when they will be carried out. With respect to payment, the Commission notes that "where the collaborative platform is merely processing the payment deposited by a user and passes it on to the provider of the underlying service, this does not imply that the collaborative platform is determining the remuneration." ${ }^{\prime 99}$ As to whether or not the worker is dependent, it does not matter that there is actual supervision or management. The Commission's analysis seems to suggest that in most cases, independents will not fulfill this criterion.

On the other hand, some scholars have noted that in practice many of the sharing economy platforms do supervise the performance of the services - however, this is done by setting internal standards for quality of service and through user ratings. Platforms do make suggestions as to what the "Uber" experience should feel like - e.g. availability of an umbrella in the car, playing jazz music, etc. While these are not required as such, they become norms which consumers accept as standards of service

\footnotetext{
${ }^{75}$ Khaleeli, 'The truth about working for Deliveroo, Uber and the on-demand economy' The Guardian (15.06.2016) < https://www.theguardian.com/money/2016/jun/15/he-truth-about-working-for-deliveroo-uber-and-the-on-demand-economy >. To quote from the article: "We are employed as "independent contractors" but that's just ridiculous legal mumbo-jumbo, to allow the company to duck its responsibilities. It's not flexible either. We used to have a system where you could swap shifts with people but they said it was too chaotic. Now you do the same shifts every week. [Deliveroo says that while work sessions are booked in advance in London, its riders prioritise flexibility and are free to tell Deliveroo when they wish to work and for how long. They say this flexibility would be lost if riders had to fit into the current structures for employees, resulting in benefits such as sick pay.]"

${ }^{76}$ Kolhatkar, "Juno Takes on Uber" (10.10.2016, The New Yorker). A driver interviewed notes that switching between the two apps is risky "because if you turned down an Uber pickup to take one from Juno your Uber rating might take a hit."

${ }^{77}$ Aloisi op cit. supra note 39 at 669.

${ }^{78}$ European Commission, 'A European agenda for the collaborative economy' (Communication) COM (2016) 356 final, p. 12 referring to the criteria in Jany.

${ }^{79}$ Ibid., p.12.
} 
and use to judge the driver according to these standards in the rankings. ${ }^{80}$ Ratings are certainly important and can serve as the basis for ending contractual relationships, which has led some to call them an "endless probation period" ${ }^{81}$ Subordination is a difficult criterion especially since in some cases it will be more visible than others. The comparison will be especially difficult where work performed by self-employed does not have a salaried equivalent.

As evident, this prong of the test is not only ambiguous for independents claiming a 'worker' status; it is open to manipulation by employers eager to avoid the consequence of labor regulations. Smart companies can exploit the deficiencies of the concept of subordination to take measures to avoid the classification of their contractors as "employees". Thus the problem still stands - that precarious independents dealing with much more powerful contracting partners will not fall under the labor rules but will fall under the competition rules.

\subsection{The independence and commercial risk requirement}

The Court has held that one of the main differences between a worker and an undertaking is that an undertaking is an economic entity which bears its own financial and commercial risk and assumes responsibility for any damages flowing from its operations or caused by its workers.

The perversion of this requirement is that although commercial independence is the case for many self-employed, it is also not necessarily the first choice for many of them. The social science literature speaks of persons "pushed" into self-employed since for many of them this is hardly a matter of choice, but of necessity. According to Buschoff and Schmidt, some self-employed are "opportunity start-ups" while others are "necessity start-ups". Discontent about risk is evident in the number of lawsuits and media reports. Independents engaged via online platforms such as Uber, Handy, Task Rabbit and AirBnB have lamented the fact that they are forced to bear their own risk when doing jobs for customers and that they are not covered by any sort of insurance policy from the company. ${ }^{82}$

This requirement is grounded in a presumption which dates to the time when most self-employed were genuine entrepreneurs. However, as argued, this is a presumption which does not hold true anymore. It is not justified to assume that the majority of self-employed today willingly give up the comfort of an employment relationship in order to enjoy greater flexibility, greater autonomy, greater potential for financial gain and the possibility to grow their own business.

Yet, the notion that self-employment is voluntary, seems entrenched in EU law. Evidence of that is the Opinion of AG Wahl in FNV Kiem who noted that "the higher risks and responsibilities borne by the self-employed are, on the other hand, meant to be compensated by the possibility of retaining all profit generated by the business." ${ }^{13}$ The possibility for profit, growing a business, or developing own customer base is an empirical question that could be tested in Court. For instance, the argument made by Uber in the context of a lawsuit in front of a UK employment tribunal that Uber helps drivers grow as entrepreneurs was rejected by the tribunal. The judge reasoned:

\footnotetext{
${ }^{80}$ Todoli-Signes, op cit. supra note 40 at 7.

${ }^{81}$ Aloisi, op cit. supra note 39 at 671.

${ }^{82}$ Many independents have expressed their concern about the lack of protection from the platform and the fact that when serving a client they find themselves "on their own". Uber drivers, Handy cleaners, and Airbnb hosts have all expressed worry about their personal safety and their property. While some companies such as Handy practice blacklisting problematic customers who harass workers, their own responsibility does not seem to stretch far. See Khaleeli op cit. supra note 75.

${ }^{83}$ Case C-413/13 FNV Kunsten Informatie en Media v Staat der Nederlanden [2014] Opinion of Advocate General Wahl ECLI:EU:C:2014:2215, [45].
} 
'The notion that Uber in London is a mosaic of 30, 000 small businesses linked by a common 'platform' is to our minds faintly ridiculous. In each case, the 'business' consists of a man with a car seeking to make a living by driving it.' Ms Bertram spoke of Uber assisting the drivers to "grow" their businesses, but no driver is in a position to do anything of the kind, unless growing his business simply means spending more hours at the wheel. Nor can Uber's function sensibly be characterized as supplying drivers with "lead". That suggests that the driver is put into contact with a possible passenger with whom he has the opportunity to negotiate and strike a bargain. But drivers do not and cannot negotiate with passengers (except to agree a reduction of the fare set by Uber). They are offered and accept trips strictly on Uber's terms. ${ }^{184}$

The 'commercial independence' prong of the employment test could potentially be improved by testing for 'entrepreneurship' or possibility of profitability - e.g. by showing that the risk taken by choosing self-employment could, in theory, be rewarded by gain, notwithstanding the possibility of a loss. The EU law test for a 'worker', however, specifically rules out such considerations..

The ECJ has rejected 'an entrepreneurship' test in the context of claims of self-employment in the past. The Court was presented with the choice to adopt a stricter entrepreneurship test in the Jany case. ${ }^{85}$ In this case, the Netherlands government sought to clarify whether sex workers from Poland and the Czech Republic could take advantage of provisions under the Association Agreements to take up work as self-employed in the Netherlands. ${ }^{86}$ The Netherlands government argued that there should be some minimum requirements for the category of self-employment such as: that the work in question must be skilled work, that a business plan must be available, that the business operator should be in charge of managing the business and not only performing the work, that the business operator must invest and have long-term commitments. ${ }^{87}$ The Court, however, did not accept these additional requirements. Similarly, in the context of competition law, the Court has rejected stricter entrepreneurship criteria - such as a requirement that an economic activity should require a "combination of material, non-material and human resources". 88

The outcome is not favorable for the 'new self-employed': one need not be tested for genuine entrepreneurship in order to be treated as an enterprise under EU competition law. At the same time, a position of commercial independence - whether desired or not - is enough to rule out the application of labor law. This situation reflects the broad scope of the EU competition provisions and the much narrower scope of the concept of 'worker'.

\subsection{Marginal and ancillary activity for multiple clients}

Another major roadblock in the concept of work and worker has to do with the requirement that the relationship with the client is one of a certain stability or a long-term nature. This is a big challenge for the newest type of self-employed - those performing work "on-demand" for different clients and especially those engaged in crowd-sourcing work.

\footnotetext{
${ }^{84}$ Case Numbers: 2202551/2015 \& Others Mr Y Aslam, Mr J Farrar and Others -V- Uber [2016], para. 90.

${ }^{85}$ Case C-268/99 Jany and Others.

${ }^{86}$ Under the Association Agreements at the time, they could not benefit from the free movement of workers provisions but could benefit from the freedom of establishment.

${ }^{87}$ Case C-268/99 Jany and Others, [24], question 5.

${ }^{88}$ Case C-35/96 Commission v Italy (CNSD) [1998] ECLI:EU:C:1998:303, [38].
} 
On numerous occasions, the Court has held that the concept of work excludes "marginal and ancillary activity". ${ }^{89}$ The Court stated in Asscher:

"It is settled law that any person who pursues an activity which is effective and genuine, to the exclusion of activities on such a small scale as to be regarded as purely marginal and ancillary, is to be treated as a 'worker' within the meaning of Article 48 of the Treaty. According to the case-law, the essential characteristic of the employment relationship is that for a certain period of time a person performs services for and under the direction of another person in return for which he receives remuneration. ${ }^{90}$

With respect to this requirement, the European Commission is of the opinion that in the case of the collaborative economy most participants would not qualify as workers although the actual outcome might differ in court. ${ }^{91}$ When it comes to Member State labor law, national courts differ in their assessment as to the necessary threshold - in terms of time spent working or wages earned - in order to qualify as a worker. ${ }^{92}$

This issue, perhaps more than any other, reveals the fundamental flaws of the 'worker' category, to which all forms of protection are linked. The question is: can the traditional concept of 'worker' possibly be broadened to include persons who provide services to multiple clients on an irregular basis, and often for short periods of time such as ten minutes? If that would be possible then the newest type of self-employed - on-demand workers engaged via matchmaking or crowdsourcing platforms could be covered. However, stretching the definition of a worker to cover even the most limited participation in labor markets would make the category of 'worker' over-inclusive. Doing so would put strain on the current system of labor protection as it would extend protection to individuals whose interaction with labor markets is sporadic. As a side effect, it could even incentivize more traditional 'self-employed' such as members of the liberal profession to adapt their behavior in order to take advantage of protections.

By contrast, there are no minimum threshold requirements linked to the concept of 'undertaking' under competition law. There is no absolute minimum turnover or period of being active on the market. The concept of undertaking simply covers "the offer on the market of goods and services". This means that even where the concepts of labor law cannot be stretched to cover the newest selfemployed, competition law remains relevant. Therefore, it is also important to consider the possibilities for exemption and even for protection not under labor law, but under the competition laws.

\subsection{Blurring conceptual boundaries}

Project-based, on-demand work in a self-employed capacity is arguably on its way to becoming the norm..$^{93}$ This argument resonates with the communication from the European Commission, which

\footnotetext{
${ }^{89}$ For instance, the issue of working for a limited number of hours has been discussed by the Court with respect to the so called 'zero hour' or 'on-call' contracts. The Court has considered that the existence of such a contract could indicate an employment relationship but that it is up to the national courts to determine this while taking into account the duration of activities and irregular nature. See Verschueren, 'Being Economically Active: How It Still Matters' in Verschueren (ed.), Residence, Employment and Social Rights of Mobile Persons: On How EU Law Defines Where They Belong (Intersentia, 2016) at 199. In the Raulin case the Court determined that work for limited hours could be an indication that the activity in question is of purely marginal or ancillary nature. See Case C-357/89 V. J. M. Raulin v Minister van Onderwijs en Wetenschappen [1992] ECLI:EU:C:1992:87, [11-14].

${ }^{90}$ Case C-107/94 P. H. Asscher v Staatssecretaris van Financiën (Asscher) [1996] ECLI:EU:C:1996:251, [25-26].

${ }^{91}$ European Commission, 'A European agenda for the collaborative economy' (Communication) COM (2016) 356 final, 13.

92 O’Brien, Spaventa, and de Coninck (FreSsco network) op. cit. supra note 34 at 27-29.

${ }^{93}$ Fudge op. cit. supra note 27; Gratton, The Shift: The Future of Work Is Already Here (Harper Collins Business 2011).
} 
notes that the rise of the sharing economy is indicative of a "structural shift" which is already visible in the fact that temporary and part-time work is on the rise, many people hold multiple jobs and there is increasingly blurring of the distinction between workers and self-employed ${ }^{94}$ Importantly, these developments affect not only the markets for 'menial' labor such as parcel delivery; they are expected to affect knowledge workers as well. ${ }^{95}$ The challenge is how to regulate the new labor markets in order to preserve the dignity and livelihood of workers while also tapping into the potential for efficiency and increased labor participation which is opened up by new forms of work.

The above section shows that the concept of a worker is not flexible enough to accommodate the developments on labor markets. This challenge is well summed up by the metaphor employed by Judge Chhabria in the case against Uber's competitor Lyft: namely, that deciding whether the self-employed drivers are 'workers' or 'employees' would amount to being "handed a square peg and asked to choose between two round holes. ${ }^{96}$ Given the difficulties in constructing a labor law definition which would encompass vulnerable self-employed, it is worth considering whether there is the possibility of escaping the competition laws.

\section{The competition law concept of 'undertaking': broad concept,} narrow exception

The EU competition provisions are addressed to "undertakings" of all sizes - big and small. There is no "de minimis" ruling when it comes to the definition of the concept of undertaking. Once an entity is deemed to fulfil the criteria for an "undertaking", the EU rules on competition apply. The key question is whether one is engaged in what the Court calls "economic activity", a concept referring to the placing of goods or services on the market. ${ }^{97}$ The concept of undertaking has long been applied to various selfemployed individuals including farmers and butchers, ${ }^{98}$ self-employed opera singers, ${ }^{99}$ boat owners providing water transport services, ${ }^{100}$ inventor-consultants, ${ }^{101}$ independent professionals such as lawyers ${ }^{102}$ and doctors, ${ }^{103}$ and independently employed customs agents ${ }^{104}$. At the national level,

\footnotetext{
${ }^{94}$ European Commission, 'A European agenda for the collaborative economy' (Communication) COM (2016) 356 final, p. 11.

95 Gratton op. cit. supra note 93.

${ }^{96}$ See Rogers, 'Redefining Employment for the Modern Economy' American Constitution Society for Law \& Policy (Issue Brief October 2016), at 4. See Cotter v. Lyft, Inc., 60 F. Supp. 3d 1067 (2015).

97 See e.g. See Joined Cases C-180/98 to C-184/98 Pavel Pavlov and Others v Stichting Pensioenfonds Medische Specialisten [2000] ECLI:EU:C:2000:428, [75]; Case C-475/99 Ambulanz Glöckner v. Landkreis Aüdwestpflaz [2001] ECLI:EU:C:2001:577, [19]; Case C-118/85 Commission of the European Communities v Italian Republic [1987] ECLI:EU:C:1987:283, [7]; Case C-35/96 Commission of the European Communities v Italian Republic (CNSD) [1998] ECLI:EU:C:1998:303, [36]; Case C-205/03 P Federación Española de Empresas de Tecnología Sanitaria (FENIN) v Commission of the European Communities [2006] ECLI:EU:C:2006:453, [25].

98 Joined cases T-217/03 and T-245/03 Fédération nationale de la coopération bétail et viande (FNCBV) (T-217/03) and Fédération nationale des syndicats d'exploitants agricoles (FNSEA) and Others (T-245/03) v Commission of the European Communities (French beef) [2006] ECLI:EU:T:2006:391.

${ }^{99}$ Commission Decision of 26 May 1978 relating to a proceeding under Article 85 of the EEC Treaty (IV/29.559 - RAI/UNITEL) OJ L 157 , 15/06/1978, p. 39-41.

100 See Case IV/31.029 - French inland waterway charter traffic: EATE levy, Commission Decision of 10 July 1985 relating to a proceeding under Article 2 of Council Regulation (EEC) No 1017/68 applying rules of competition to transport by rail, road and inland waterway, OJ [1985] L 219/35, [40].

${ }^{101}$ Reuter/BASF [1976] OJ L 254/40, at 254/45.

${ }_{102}$ Case C-309/99 Wouters and others [2002] ECLI:EU:C:2002:98; C-35/99 Arduino [2002] ECLI:EU:C:2002:97.

${ }^{103}$ Joined Cases C-180/98 to C-184/98 Pavel Pavlov and Others v Stichting Pensioenfonds Medische Specialisten [2000] ECLI:EU:C:2000:428.

${ }^{104}$ See Case C-35/96 Commission v Italy [1998] ECLI:EU:C:1998:303, [37-38].
} 
freelance actors ${ }^{105}$ and substitute musicians ${ }^{106}$ have also been considered undertakings for the purpose of applying national competition rules.

Hence we should turn to the case law in which workers had to be distinguished from undertakings for the purpose of applying competition law. ${ }^{107}$ Based on the case law, the following criteria can be distinguished: the engagement in "economic activity" and commercial independence. Economic activity essentially requires that the undertaking is engaged in the provision of goods or services on the market. ${ }^{108}$ Unlike the requirement for workers that "marginal and ancillary" activity be excluded, there is no similar requirement with respect to economic activity. ${ }^{109}$ With respect to commercial independence, the Court's analysis mirrors the analysis applied to distinguish workers from selfemployed. Commercial independence requires that the entity is in fact a separate entity, e.g. independent from the principal. ${ }^{110} \mathrm{~A}$ key factor in establishing independence is determining who bears responsibility for commercial risk. ${ }^{111}$ Importantly, just as it rejected the need for self-employed to meet any entrepreneurship criteria, the Court has not required that an undertaking behave like "a company". Thus, there is no need for investment or a "combination of material, non-material and human resources"112.

An exception was introduced in the FNV Kiem judgment of the Court of December 2014. In this judgment, the Court drew an additional distinction between "false self-employed" and genuine selfemployed, the former escaping the definition of "undertaking" for the purpose of EU competition law. The judgment preserves the traditional distinction between "worker" and "undertaking", but notes that self-employed who meet the criteria for "worker" escape the competition rules. This section argues that while the judgment is to be praised for acknowledging the problem of bogus selfemployment, it does not change much for the 'new self-employed'.

\subsection{The FNV Kiem judgment}

The reference for a preliminary ruling arose in the context of a dispute concerning a reflection document issued by the Dutch competition authority. ${ }^{113}$ The document stated that a collective labor agreement fixing minimum tariffs concluded on behalf of self-employed workers is incompatible with the competition rules. The self-employed in question were substitute orchestra musicians, and the trade union in question represented both those regularly employed as orchestra musicians and the

\footnotetext{
${ }^{105}$ Irish Competition Authority, Decision No E/04/002 (Case COM/14/03) Agreements between Irish Actors' Equity SIPTU and the Institute of Advertising Practitioners in Ireland concerning the terms and conditions under which advertising agencies will hire actors.

${ }^{106}$ Case C-413/13 FNV Kiem; See in this respect the Dutch Competition Authority (Nederlandse Mededingingsautoriteit), Cao-

tariefbepalingen voor zelfstandigen en de Mededingingswet: visiedocument (Collective labor agreements determining fees for selfemployed and the competition law: a reflection document) (2007).

${ }^{107}$ Case C-22/98 Becu and Others [1999] ECLI:EU:C:1999:419, Case C-309/99 Wouters and others [2002] ECLI:EU:C:2002:98; Case C-413/13 FNV Kiem.

${ }^{108}$ Case C-35/96 Commission v Italy (CNSD) [1998] ECLI:EU:C:1998:303, [36].

109 There exist so called "de minimis" exceptions from the competition rules. However, these are linked - in particular in the case of Art 101 TFEU - to the notion of "appreciability" of the restriction of competition and not to the concept of undertaking as such. See section 4.1. of this paper.

${ }^{110}$ Case C-217/05 Confederación Española de Empresarios de Estaciones de Servicio [2006] ECLI:EU:C:2006:784, [45]; Case C-413/13 FNV

Kiem , [27].

111 Joined Cases 40/73 to 48/73, 50/73, 54/73 to 56/73, 111/73, 113/73 and 114/73 Suiker Unie and Others v Commission [1975] ECR 1663, [541]; Case C-35/96 Commission v Italy (CNSD), [37], Case C-413/13 FNV Kiem, [33].

112 Case C-35/96 Commission v Italy (CNSD), [38].

113 Dutch Competition Authority (Nederlandse Mededingingsautoriteit), Cao-tariefbepalingen voor zelfstandigen en de Mededingingswet: visiedocument (Collective labor agreements determining fees for self-employed and the competition law: a reflection document) (2007).
} 
substitutes who had a freelance status. After the opinion was issued, negotiations between the employers' association and the union broke down. The union started proceedings with the purpose of obtaining a declaration that it is not contrary to Dutch or EU competition law for self-employed substitutes to conclude a collective bargaining agreement setting minimum tariffs with the employers. The national court referred two questions, essentially reflecting the two cumulative criteria for established in previous case law related to competition law and collective bargaining. ${ }^{114}$ Firstly, it asked if minimum-fee provisions in a collective bargaining agreement covering self-employed who perform for an employer the same work as regular employees could be seen as falling outside the scope of Article 101 TFEU on the ground that these provisions are included in a collective labor agreement. In its second question the Court asked if the provisions can be interpreted as falling outside the scope of Article 101 on the ground that they improve the working conditions of workers. ${ }^{115}$

In response to the questions, the Advocate General did not address the functional similarity between self-employed substitutes and employed musicians, and their equal position with respect to being in a weaker bargaining position; in fact, he considered that drawing a distinction between self-employed and workers would be workable, despite the heterogeneity of the self-employed category. ${ }^{116}$ Instead, he suggested carving an exception for collective bargaining agreements depending on the purpose they pursue. His proposed solution was for trade unions to be able to conclude agreements which affect self-employed but only when doing so is for the purpose of preventing social dumping. This would be verified by following a two-step test. Firstly, courts would have to ascertain the presence of "a real and serious risk of social dumping" as in where there is evidence that workers are likely to be replaced with self-employed; the provisions in the collective bargaining agreement need to be essential to preventing this outcome. ${ }^{117}$ Secondly, the provisions in question would have to pass a proportionality analysis to make sure that the provisions do not go beyond what is necessary to improve the situation of workers. ${ }^{118}$ The Advocate General's approach is firmly premised on the idea that self-employed cannot escape the scope of the competition rules and that while the Treaties aim to promote the protection of workers they never mention the protection of self-employed.

The Court did not follow this approach. Instead, it made a distinction between two types of selfemployed: genuine self-employed and 'false' self-employed. The result of FNV is as follows: it is confirmed that self-employed are to be considered undertakings for the purpose of competition law; in this case, there is no exception for making collective bargaining agreements. On the other hand, should these self-employed be "false self-employed" in the sense of performing the same work as regular workers, a collective bargaining agreement covering them would fall outside the scope of the competition rules. ${ }^{119}$

\footnotetext{
${ }^{114}$ C-67/96 Albany International BV v Stichting Bedrijfspensioenfonds Textielindustrie [1999] ECLI:EU:C:1999:430; C-115/97 to C-117/97 Brentjens' Handelsonderneming BV v Stichting Bedrijfspensioenfonds voor de Handel in Bouwmaterialen (Brentjens) [1999] ECLI:EU:C:1999:434; C-219/97 Maatschappij Drijvende Bokken BV v Stichting Pensioenfonds voor de Vervoer- en Havenbedrijven (Drijvende Bokken) [1999] ECLI:EU:C:1999:437; C-222/98 Hendrik van der Woude v Stichting Beatrixoord (van der Woude) [2000] ECLI: EU:C:2000:475. 


\subsection{FNV Kiem: a narrow escape for bogus self-employed}

The judgment in FNV Kiem was quickly welcomed as an affirmation of the Court's intention to support measures enhancing solidarity and the spirit of worker protection. ${ }^{120}$ However, there are reasons to remain skeptical about the impact of the Court's judgment. Commentators noted that the criteria for determining whether a self-employed worker is 'false' or 'genuine' are vague and open to misinterpretation. ${ }^{121}$ The judgment does not articulate clear criteria for when a worker classifies as 'false self-employed' but makes it an empirical test based on the definition of a worker, essentially leaving it for the national courts to identify criteria for determining whether the function performed by the self-employed is essentially the same as the function performed by regular employees.

Essentially, the judgment in FNV Kiem is an affirmation of the 'worker' test which probes for subordination and commercial independence. Thus, it only addresses the problem of the 'bogus' selfemployed but not for the 'new' self-employed. The difference is worth repeating: 'bogus' selfemployed are 'mis-classified' workers and a court would have no trouble declaring that they are entitled to the legal status of a 'worker'. By contrast, many of the new self-employed, especially those engaged in crowdwork or the sharing economy, cannot hope to be declared 'workers' by a court because they will never meet the conditions of the 'worker' test. The FNV Kiem ruling is thus irrelevant to their situation. ${ }^{122}$ It provides no solution for situations in which there are no other 'regular employees' that one can compare against. Thus, it does not apply to freelancers providing services via platforms arranging for crowdsourcing work or on-demand work as most of the time the service they provide cannot be compared with the job done by a "regular employee" because no such employee exists in the organization in question. The ruling is also irrelevant to the status of those self-employed, whose employers will take the necessary measures to avoid a finding of an employment relationship. These freelancers will continue to fall under the competition rules and will be - much as utility companies or high tech giants such as Microsoft - subject to the same rules and prohibitions.

There is a further consequence which has to do with the model of industrial relations. FNV Kiem does nothing to remedy the legal uncertainty for a trade union which aims to increase its membership by attracting self-employed. All FNV Kiem introduces is a rebuttable presumption that the defendant in an antitrust investigation - the employers' organization and the trade union ${ }^{123}$ - would have to prove wrong. This is a big risk for both parties as antitrust fines can be as high as up to $10 \%$ of the global turnover of the entity.

\footnotetext{
${ }^{120}$ See e.g. Rombouts, 'Commentary: Substantive scope of Article 101(1) TFEU with regard to collective labour agreements and the issue of false self-employed service providers: European Court of Justice Judgment of 4 December 2014: Preliminary Ruling in the proceedings of FNV Kunsten Informatie en Media v Staat der Nederlanden, Case C-413/13 ('FNV Kiem')' (2015) International Labor Rights Case Law Journal; See also Ankersmit, 'Albany revisited: the Court directs NCA to carry a more social tune' (3 March 2015) European Law Blog< http://europeanlawblog.eu/?p=2695 >.

${ }^{121}$ Huidijk “De toepasselijkheid van cao's op zelfstandigen: wat zegt het mededingingsrecht?" (16 April 2015) AKD Blog < http://blogs.akd.nl/2015/de-toepasselijkheid-van-caos-op-zelfstandigen-wat-zegt-het-mededingingsrecht/ >. The author, a lawyer practicing EU and competition law at a Dutch law firm, notes that there is much uncertainty over whether a self-employed worker will be considered "false self-employed" or genuine self-employed. See also Pennings op. cit. supra note 73.

122 Importantly, the criteria are based on a comparison with what a typical worker does but in many cases there will be no immediately available comparison. The challenge is for those self-employed engaged in novel types of work for which no clear equivalents in terms of salaried labor exist. One could compare the work done by a regular worker under an employment contract and compare it to the work done by a substitute.

${ }^{123}$ In this case, the cartel would be 'vertical' so employers would also be liable if they enter into the agreement.
} 
The consequences of legal uncertainty were already anticipated in the opinion of AG Wahl who rejected the approach ultimately taken by the Court. ${ }^{124}$ In his view: "I do not see how it could be in the interests of the social partners to negotiate and enter into collective agreements whose validity in a number of specific cases is at best uncertain, and thus easily the source of dispute, and which, as a result, fail to set the labour standards in the sector covered." 125 Such uncertainty threatens to make unions irrelevant for self-employed, and thereby weaken unions themselves as unions have been struggling to recruit members in the past years.

\section{Beyond definitions: in search of an exception to the cartel prohibition for new self-employed}

It is certainly regrettable that the ECJ did not seize the opportunity to recognize the difference between 'new' self-employed and traditional self-employed and to appreciate that the former category is much broader than 'bogus self-employed'. However, criticism of the outcome in FNV Kiem should also be realistic: there is no easy solution to the problem of unequal bargaining power of precarious selfemployed. Adjustments of the definitions of 'worker' or 'undertaking' can have undesirable side effects. In the case of the definition of a 'worker', it would mean broadening the scope of the term beyond recognition with the consequence that even occasional transactions can imply the existence of a labor relationship. Such an outcome destroys the much needed flexibility in labor markets that the EU has been pursuing. ${ }^{126}$ At the same time adjusting the scope of the term 'undertaking' to exclude self-employed from the scope of the competition rules could lead to the undesirable consequences associated with cartels - namely, higher prices, lower quality and less innovation. Certainly, giving a 'carte blanche' for price fixing to all self-employed, or even just to the self-employed without personnel is quite problematic. Allowing doctors, lawyers, or accountants, but also locksmiths, craftsmen, or plumbers to price-fix would be severely damaging for the consumers of such services. Finally, it is not clear if adjusting definitions would be effective in the long-run as companies also adjust their business model to the updated legal categories.

A less drastic approach might be to search for exceptions to the cartel prohibition specifically related to collective bargaining. The Advocate General in FNV Kiem proposed a solution on the basis of Albany, but the Court decided not to follow this approach. ${ }^{127}$ This section explores other possibilities for avoiding the prohibition within Article 101 TFEU by first looking at the possibilities for escaping Art. 101 (1) and secondly, considering the possibilities for exemption under Art. 101 (3) TFEU. Finally, the section comments on the enforcement priorities of competition law authorities

\subsection{Agreements not restricting competition under Art. 101 (1) TFEU}

\footnotetext{
${ }^{124}$ Case C-413/13 FNV Kiem, Opinion of Advocate General Wahl, [63]. In his view the distinction self-employed and worker was workable and despite the heterogenous nature of the class of self-employed he did not recommend carving out an exception.

${ }^{127}$ Labor law professor Frans Pennings argues that the AG's approach is quite difficult for the national courts and, furthermore, of limited practical usefulness. It means that one has to be able to show the fact that in the absence of agreement replacing workers with independents has already taken place - a point in time at which a collective bargaining agreement is probably too late. See Pennings op. cit. supra note 73 at 114 .
} 
Are there circumstances under which collective setting of tariffs by freelancers could fall outside the scope of Article 101(1) TFEU? In general, restrictive measures taken by trade associations - even those entered into with the blessing of the state - have not escaped the competition rules. ${ }^{128}$ Nonetheless, there are few situations in which a measure restricting competition at first sight can nonetheless be deemed as not "restrictive of competition" in the meaning of Article 101 (1) TFEU. However, the criteria for fulfilling this condition are rather strict - the measure has to be in pursuit of the public interest, and the restriction has to be proportionate. The case law on the liberal professions can be instructive in this regard. In Wouters, the Court held that a decision by a professional association of lawyers to prohibit partnerships involving lawyers and accountants fell outside the scope of Article 101 (1) TFEU on grounds of pursuing a public interest. ${ }^{129}$ Thus, although lawyers were held to be undertakings, and the Dutch bar - an association of undertakings, the measure was excluded from Art. 101 (1) TFEU. In doing so, the Court took into account the proportionality of the measure and the fact that it pursued a public objective. ${ }^{130}$

With respect to the joint setting of minimum tariffs by self-employed, two cases against Italy provide some insight. In CNSD, a national measure requiring the National Council of Customs Agents, who were self-employed, to adopt compulsory tariffs for all agents was found to be in breach of Article 101 (1) TFEU. ${ }^{131}$ At the same time, in another case against Italy, the Court found that a national measure permitting the fixing of minimum and maximum tariffs in the case of lawyers and notaries, was exempt from Article 101 TFEU. The main difference between the two cases seems to lie in the extent to which there was supervision in the public interest - in the Arduino case, the Court found that the governance structure was such as to prevent conflicts of interest so the setting of tariffs was allowed; ${ }^{132}$ by contrary in CNSD, the Court found such safeguards to be lacking. ${ }^{133}$

The obvious conclusion is that the scope of these exceptions is rather limited and it can hardly be said that a collective bargaining agreement by self-employed would meet 'public interest' criteria. But even if that could be argued that a certain group of self-employed could benefit from an exception, the problem will remain for the rest of the self-employed. It is unlikely to be able to show that a variety of crowd-workers have a sufficient group identity to even seek protection as a group.

Another suggestion for protecting independents could be to have a so called de minimis exemption for micro cartels concluded by vulnerable independents. Under EU law, there is the de minimis exception first articulated by the Court in the Völk v. Vervaecke case. ${ }^{134}$ However, as clarified in the Commission guidelines regarding on the de minimis exception, this exception does not apply to agreements which have the object of restricting competition. ${ }^{135}$ Agreements fixing prices and limiting output are generally considered restrictions by object, and it is the type of category that collective bargaining on wages and terms of labor would fall under. The Court'These agreements are considered so egregious,

\footnotetext{
${ }^{128}$ See Case C-123/83 Bureau national interprofessionnel du cognac v Guy Clair (BNIC v Clair) [1985] ECLI:EU:C:1985:33; Joined cases C101/07 P and C-110/07 P Coop de France bétail et viande and Fédération nationale des syndicats d'exploitants agricoles (FNSEA) and Others $v$ Commission of the European Communities [2008] ECLI:EU:C:2008:741.

${ }^{129}$ Case C-309/99 Wouters and others, [97].

130 Ibid., [109-110].

${ }^{131}$ Case C-35/96 Commission v Italy (CNSD) [1998].

132 Case C-35/99 Arduino [2002] ECLI:EU:C:2002:97, [44].

${ }^{133}$ Case C-35/96 Commission v Italy (CNSD), [43].

${ }^{134}$ Case C 5/69 [1969]. In it the Court held that: "[...] an agreement falls outside the prohibition in [Article 101] when it has only an insignificant effect on the markets, taking into account the weak position which the persons concerned have on the market of the product in question." In this case, one of the parties had 0.08 market share of the Community market, 0.2 percent in Germany and 0.6 percent in Belgium and Luxembourg.

135 European Commission, Notice on agreements of minor importance which do not appreciably restrict competition under Article 101(1) of the Treaty on the Functioning of the European Union (De Minimis Notice) [2014] OJ C 291/01, [2].
} 
that they are not permitted at any level of market share. For instance, in the 2013 judgment in Schenker, the Court found that a cartel with a maximum market share of less than $4 \%$ of the relevant market in Austria was in breach of Art. 101 TFEU. ${ }^{136}$ There is, of course, the possibility that de minimis exemptions be adopted in national competition law. However, although there might be thresholds at the national level, their applicability is limited by the presence of cross-border effects. ${ }^{137}$

Although introducing an exception by setting certain thresholds, it is also worth wondering what the effectiveness of such a measure would be. If the problem at hand is the imbalance in terms of bargaining power between platforms and self-employed, then possibilities for minor increases in bargaining power may not offer a sufficient solution.

\subsection{Escaping the cartel prohibition via Article 101 (3)}

Article 101 (3) provides the possibility to exempt restrictions on competition on grounds of furthering technological progress or improving outcomes for consumers. In the case of agreements aiming to improve the position of suppliers which might result in price increases for consumers and no clear advantages in terms of efficiency, the first two criteria of the four cumulative conditions of the test will certainly not be met.

\subsection{Adjusting enforcement priorities?}

Prosecuting cartels has not always been the priority for the EU Commission. ${ }^{138}$ However, with the modernization of EU competition law, fighting cartels has become core business for the Commission and national enforcers. Cartel investigations are also an important element of evaluating the efficiency of national authorities: if an authority is evaluated on the number of decisions taken or on what they have delivered in terms of overcharges to consumers prevented, cartel investigations score on both points. Cartel cases also tend to be relatively 'clear-cut' in the sense that proving the existence of the agreement suffices for showing a breach. By contrast, cases involving abuses of power require more sophisticated argumentation and theories of harm.

Thus, although one might wonder if national competition authorities would be willing to expend time and resources to prosecute very small cartels, practice shows that they do. For instance, the Dutch competition authority has a track record of investigating small cartels. In 2011, the authority fined ten window cleaning enterprises in the city of the Hague for agreeing to split the market - the market in

\footnotetext{
${ }^{136}$ See Case C-681/11 Bundeswettbewerbsbehörde, Bundeskartellanwalt v Schenker \& Co. AG and Others (Schenker) [2013]. Importantly, the judgment went against an assurance which had been issued by the Austrian competition authority that such an agreement would be exempt.

${ }^{137}$ For instance, self-employed without personnel in the Netherlands may enjoy exemption from the competition rules provided 1 ) that they meet certain turnover criteria $(5.5 \mathrm{mln}$ euros) and 2$)$ that there are no more than 8 enterprises involved. We should stress, however, that an effect on cross-border trade is easily found in EU competition law, so it is to be doubted to what extent such national exceptions have any meaning in practice.

${ }^{138}$ See European Commission, White Paper on Modernisation of the Rules Implementing Articles 85 and 86 of the EC Treaty [1999], 5. See also I Maher, 'Competition Law and Transnational Private Regulatory Regimes: Marking the Cartel Boundary' (2011) 38 (1) Journal of Law and Society, 119.
} 
this case being the streets of the De Hoornse Zoom suburb. ${ }^{139}$ The cleaners in question were small enterprises with limited turnover so they were fined with 1000 euros each except for one cleaner who, due to his old age and other circumstances, was not active in the business anymore and who received a symbolic fine of 1 euro. ${ }^{140}$ Agreements on annual price increases decided by a cleaner's branch organization were found in breach of competition law and led to million euro fines. ${ }^{141}$ Most of the enterprises in question were small enterprises, likely including many self-employed. ${ }^{142}$ Other national authorities have also prosecuted cartels involving micro and small enterprises. ${ }^{143}$

This paper in no way argues that competition authorities should stop fighting cartels. Even small and local cartels can be harmful to consumers and, more generally, to a growth- and innovation-oriented economy. It does, however, raise the issue of what we might consider 'one-sided enforcement': fighting cartels among suppliers (in this case suppliers of labor) while failing to take measures against abuses by powerful contracting partners such as platforms.

\section{The self-employed in an Uber economy: a regulatory perspective}

It should be evident by now that the issue of protecting the new self-employed by the traditional mechanism of collective bargaining is not just a matter of political will: as shown, in some jurisdictions such as Ireland, there is a clear legislative desire to exempt vulnerable independents from the competition provisions. ${ }^{144}$ It is also not necessarily a problem of pro-trade EU laws versus more sociallyoriented national preferences. Rather, it is a fundamental problem of blurring boundaries between legal categories such as 'worker' and 'enterprise' - a problem which is a reflection of fundamental changes in society brought by changes in business organization, globalization, and technology.

In this situation, it is worth 'going back to basics' 145 and considering the fundamental problem that the law is trying to solve. The problem is one of economic dependence and power imbalances and the

\footnotetext{
${ }^{139}$ NMA News, "NMa fines window cleaners in The Hague for cartel activities" (29 December 2011) < https://www.acm.nl/en/publications/publication/6721/NMa-fines-window-cleaners-in-The-Hague-for-cartel-activities/> An Dutch language press release with a summary of the decision is available at $<$ https://www.acm.nl/nl/publicaties/publicatie/6623/NMa-beboetkartelafspraak-Haagse-glazenwassers/>.

${ }^{140}$ The glass cleaner in question received a symbolic fine of 1 euro. See Samenvatting van het besluit van de NMa van 20 december 2011, Zaak 6425/Glazenwassers; to be accessed via <https://www.acm.nl/nl/publicaties/publicatie/6623/NMa-beboet-kartelafspraak-Haagseglazenwassers/>

${ }^{141}$ See Nu.nl, “NMa geeft schoonmakers miljoenenboete” (19 March 2003) http://www.nu.nl/economie/122827/nma-geeftschoonmakers-miljoenenboete.html. According to the article, the branch organization OSB numbered 650 cleaning business - for the most part, small undertakings.

${ }^{142} \mathrm{Ibid}$.

${ }^{143}$ Consider the VEBIC case which was subject to a preliminary reference before the Court of Justice. The infringement in question was a price agreement between artisan bakers, ice-cream and chocolate makers in Belgium. Case C-439/08 Vlaamse federatie van verenigingen van Brood-en Banketbakkers, ljsbereiders en Chocoladebewerkers (VEBIC) VZW. [2010] ECLI:EU:C:2010:739.

${ }^{144}$ The 2001 decision of the Irish Competition Authority restricting the possibility of freelance actors to bargain collectively has caused much outrage in society and since then multiple attempts were made to legislate to address the issue of the right to collective bargaining for vulnerable self-employed, especially artists, musicians and freelance journalists. In 2010 a legislative proposal was made to amend the competition rules; however, the proposal was rejected because of concerns with compliance with the IMF/EU Financial Support program which did not allow for additional exemptions from competition law. Since then, two more attempts for legislative amendment have been made - in 2014 and 2016. Remarkably, in 2016, the proposal secured the support of all parties. See the debates in the Irish Parliament on $10^{\text {th }}$ July 2014 and $6^{\text {th }}$ July 2016 available via http://oireachtasdebates.oireachtas.ie. See additionally, European Labor Law Network website, 'ECJ Case C-413/13 (FNV Kunsten Informatie en Media)' <http://www.labourlawnetwork.eu/national_labour law/implications of ecj_rulings/_implications of ecj_rulings/prm/191/v detail/id 5332/category 17/index.html > and Dawson and Dooley, 'Irish freelances shorten the road to the promised land' (The Freelance Bulletin, July 2016).

${ }^{145}$ As argued by Brishen Rogers in Rogers, op. cit. supra note 40 at 479.
} 
likelihood that this will lead to exploitation and unfairness. ${ }^{146}$ Historically, the way to solve this problem in the context of labor provision was to provide for a minimum floor of protection via labor law complemented by the possibility for collective bargaining. By allowing workers to join forces something which companies are forbidden from doing - society ensures that unfair outcomes can be avoided; the decision to exclude antitrust rules from application was a conscious one. ${ }^{147}$ However, as this paper has shown, once labor becomes "service" and workers become 'contractors', this mechanism for protection is no longer applicable. Furthermore, as argued, given the frontier of ontime, piece-by-piece contracting, no definition of 'worker' can be conceived that will cover - in a meaningful way - all types of modern labor market engagement. Thus, we are left with a problem and no remedy.

One approach is to reject the technological developments despite the promise of efficiency and increased opportunity for labor market participation. Another approach is to search for a new remedy to the problem of vulnerability and precariousness in the context of B2B contracting for services provided by small independents. The question then becomes: what kind of regulatory strategy or strategies could solve the problem?

Looking to the legal literature and existing legal remedies, we see that there is no immediate solution to this type of problem. The problem of unfair practices or exploitation in the context of B2B relations has been recognized by policy-makers and in the literature. ${ }^{148}$ However, currently, the legal system does not have a clear and convincing answer to the question of how unfair trading terms in business to business relations (B2B) characterized by power imbalances should be regulated.

A look to the experience of farmers and small food producers is instructive in this respect. Small food producers have been complaining about unfair trading practices and abuse of power by supermarket chains for decades already. ${ }^{149}$ Still, there is no clear solution to this problem. A number of approaches: private law (contract law) and private regulatory regimes such as codes of conduct mandated by government ${ }^{150}$ or proposed by private parties ${ }^{151}$ as well as solutions through public law - both via competition law and sector-specific regulation - have been put forth to address this problem. Much

\footnotetext{
${ }^{146}$ Ibid. See also Collins op.cit. supra note 2; European Commission, 'Green Paper: Modernising labour law to meet the challenges of the 21st century' (2006) COM 708 final.

${ }^{147}$ Ichino, 'Collective Bargaining and Antitrust Laws: an Open Issue' (2001) 17 (2) The International Journal of Comparative Labour Law and Industrial Relations, 185.

${ }^{148}$ See European Commission, Green Paper on Unfair Trading Practices in the Business-to-Business Food and Non-Food Supply Chain in Europe [2013] COM (2013) 37 final; Stuyck, 'Do We Need 'Consumer Protection' for Small Businesses at the EU level' in Purnhagen and Rott (eds), Varieties of European Economic Law and Regulation (Springer Switzerland 2014), 359-368; Daskalova, The Monopsony Paradox: Buyer Power and Enforcement of the EU Antitrust Provisions (PhD thesis, 2016); Hesselink, 'Unfair Terms in Contracts between Businesses' (2011) Centre for the Study of European Contract Law Working Paper Series No. 2011/07, 1.

${ }^{149}$ For an overview, see Communication from the Commission to the European Parliament, the Council, the European Economic and Social Committee and the Committee of the Regions, "A better functioning food supply chain in Europe" (2009) COM/2009/0591 final < http://eur-lex.europa.eu/legal-content/EN/TXT/?uri=CELEX\%3A52009DC0591 > ; European Competition Network food subgroup, 'ECN activities in the food sector: Report on competition law enforcement and market monitoring activities by European competition authorities in the food sector (24 May 2012); Communication from the Commission, Tackling unfair trading practices in the business-to-business food supply chain (2014) $\operatorname{COM(2014)~} 472$ final.

150 See e.g. the UK Groceries Code Adjudicator Act 2013.

${ }^{151}$ A prominent example at the EU level is the code of conduct developed by European food and drink producers and supermarkets in the context of the Supply Chain Initiative endorsed by the European Commission. See http://www.supplychaininitiative.eu/about-

initiative/principles-good-practice-vertical-relationships-food-supply-chain. The code of conduct 'Vertical relationships in the Food Supply Chain: Principles of Good Practice' is available at https://ec.europa.eu/digital-single-market/en/content/vertical-relationships-food-supplychain-principles-good-practice-b2b-platform-0; The code is accompanied by a business-to-business (B2B) Platform for enforcement of the principles.
} 
experimentation is taking place at the national level to design the appropriate regulatory regime to deal with this issue. ${ }^{152}$

Given the difficulties in solving the problem via the labor rules, alternative possibilities are worth exploring. The regulatory perspective considers the possibilities for addressing a given societal problem by means of: ex ante public regulation or ex ante private regulation and ex post public regulation or ex post private regulation. Thinking in terms of these 'quadrants of regulation' can help in the brainstorming for solutions to the problem. ${ }^{153}$ This is summarized in the figure below.

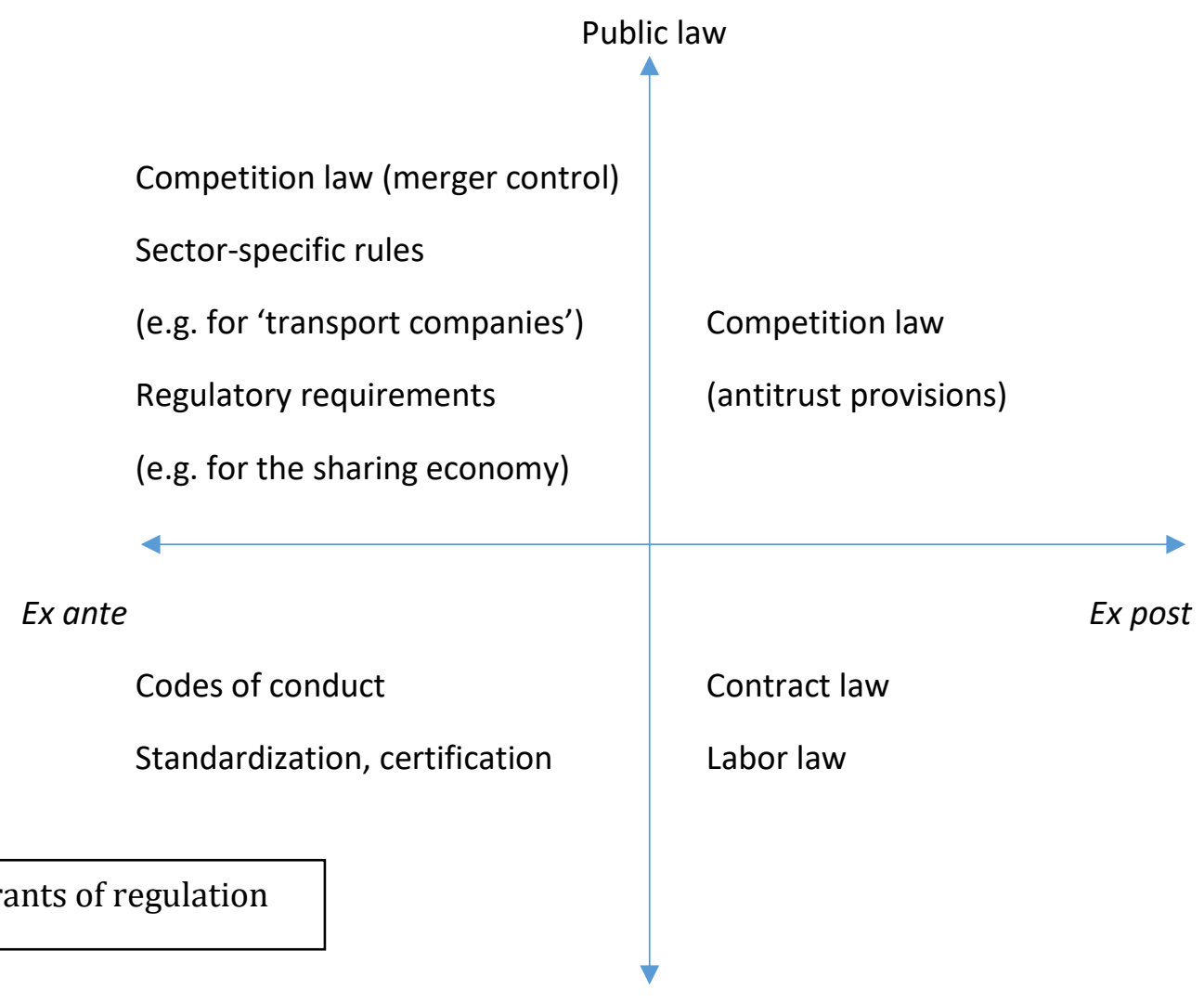

Private law

One option is a regulatory approach with a focus on a particular sector, business model, or practice i.e. rules for service providers in a particular sector such as the rules governing the liberal professions or rules targeting the 'sharing economy' or certain practices - e.g. below-minimum wage payments or unfair terms. This is a challenging approach as rules might be under-inclusive, would have to be set up ex ante and the process of creating rules and setting up an enforcement system might be lengthy.

There is also the possibility of an ex ante private regulatory approach - e.g. by means of codes of conduct. A company or industry can commit to high level of protection for contractors by means of an

\footnotetext{
${ }^{152}$ A helpful overview of the varied legal landscape with respect to stricter rules aimed to address power imbalances in the food supply chain is available in J Stefanelli and P Marsden (British Institute of International and Comparative Law), Models of Enforcement in Europe for Relations in the Food Supply Chain (23 April 2012) and College of Europe, European University Institute and Center for European Policy Studies, Study on the Legal Framework Covering Business-to-Business Unfair Trading Practices in the Retail Supply Chain (Report prepared for the European Commission, DG MARKT/2012/049/E, 2014).

153 Inspiration is drawn from Walker Smith, 'Regulation and the Risk of Inaction' in Maurer et al, Autonomes Fahren: Technische, rechtliche und gesellschaftliche Aspekte (Springer 2015), 593-609 and his graph of regulatory quadrants which is adapted for the purpose of this paper.
} 
individual or industry-wide code of conduct. There is evidence of some crowdsourcing companies experimenting along these lines. ${ }^{154}$ Websites allowing for comparison of best rates and contract terms for crowdworkers also exist, although the legal implications of such exchanges of information are not certain. ${ }^{155}$

With respect to ex post private rules, the most important regulatory tool to consider is contract law. Arguably, European contract law is not yet equipped to deal with unfair B2B practices. ${ }^{156}$ When it comes to labor relations which escape the parameters of labor law, we run into the problem of "freedom of contract". ${ }^{157}$ The assumption of relative equality of the parties to a contract is suspended in fields of law in which one party is presumed by law to be the weaker one (e.g. consumer protection law or labor law). In the context of contract law itself, this assumption can be set aside; however, this is usually done in cases where the principle of freedom of contract was blatantly compromised - as in the case of unconscionability or duress - which require specific circumstances. They ensure that no grave procedural flaws mar the outcome of the bargaining process; yet, they do not question the outcome on grounds of market failure - such as when the price paid is abusive because of substantial imbalance in bargaining power. Furthermore, contract law depends on private enforcement; this is problematic in view of enforcement as the most vulnerable contractors can face barriers to enforcement. Such barriers can be linked to resources - access to legal advice, money, time; these have been recognized as a problem in the case of enforcement of the competition rules by SMEs. ${ }^{158}$ For small companies depending on trading with large ones there are additional barriers - namely, the fear of retaliation when contesting the ongoing trading practices of an important customer. ${ }^{159}$

With respect to ex post public regulation, we might consider competition law as a solution. This suggestion may come as a surprise because competition law is often perceived to be a problem for the protection of self-employed. However, competition law is also the branch of law which ensures that economic power is not abused. It ensures - in a broad sense - that the market system is not rigged. The following section will explore the potential for addressing the problem of vulnerability of selfemployed with the tools of competition law.

\section{The role of competition law}

Competition law is the legal discipline concerned with ensuring that competition is present on the market, in particular: that companies do not manipulate the 'rules of the game' by means of conspiracy and that powerful companies do not abuse their power. With respect to abuse, it is notable that the abuse of power can be directed toward trading partners (customers or suppliers) and towards

\footnotetext{
154 There is evidence that some companies have started introducing minimum requirements for treating their independent contractors. de Stefano refers to the Code of Conduct Paid Crowdsourcing to which three crowdwork platforms in Germany have already agreed and which is endorsed by the German Crowdsourcing Association. The Code is to be found at http://crowdsourcing-code.com/. See also de Stefano op. cit. supra note 36 at 24.

155 See e.g. http://www.faircrowdwork.org/en. The website allows crowdworkers to check for the best online rates.

${ }^{156}$ Hesselink op. cit. supra note 149 and Stuyck op. cit. supra note 149.

157 Collins op. cit. supra note 2 at 375-376.

158 Këllezi, Kilpatrick and Kobel (eds), Antitrust for Small and Middle Size Undertakings and Image Protection from Non-Competitors (Springer 2014).

${ }^{159}$ See Temple Lang, 'Reprisals and Overreaction by Dominant Companies as an Anti-Competitive Abuse under Article 82(B)' (2008) 29(1) European Competition Law Review, 13; also European Commission, Green Paper on Unfair Trading Practices in the Business-to-Business Food and Non-Food Supply Chain in Europe [2013] COM (2013) 37 final section discussing the so-called "fear factor".
} 
competitors. Thus, competition law has a twofold role to play - firstly, to keep markets open and secondly, to intervene in cases where market power is abused.

Keeping markets open in this case would mean ensuring that self-employed have sufficient choice of platforms they can contract with. Merger control certainly has an important role to play in this regard. However, agreements and technical specifications which might restrict mobility and multi-homing for self-employed should also be scrutinized. Ensuring portability of user ratings is also key in making switching possible and allowing unwilling entrepreneurs the actual opportunity to make a name for themselves. The notion that workers are expendable will change as more competition develops on the market.

A second and less often considered tool of EU competition law is the prohibition of exploitative abuse by companies in a dominant position. Arguably, making sure that powerful companies do not exploit their trading partners was the original goal of Art. 102 TFEU. ${ }^{160}$ This is evident from the text of Article 102 TFEU paragraphs $a$ ) and $b$ ) which explicitly list the following as examples of abuse by the dominant company:

"(a) directly or indirectly imposing unfair purchase or selling prices or other unfair trading conditions;

(b) limiting production, markets or technical development to the prejudice of consumers;"

Paragraph a) speaks of unfairness toward contractual partners, be they consumers or suppliers, that the dominant undertaking deals with. The second paragraph seems to refer to restrictions that could impact social welfare and which manifest themselves in consumer harm.

These paragraphs are at the heart of the doctrine known as "exploitative abuse" in EU competition law. The logic of exploitative abuse is that competition law is not only to protect the horizontal competitors of the dominant undertaking; rather, it also protects the (weaker) contractual partners of such an undertaking. It recognizes that a company in a dominant position can take actions that not only seek to eliminate its competitors, but which may - simultaneously or after competitors have been excluded - harm its business partners. As such, the concept of exploitative abuse resonates with the market failure of the economic concepts of monopoly or monopsony - in which a single undertaking determines the trading conditions (price and contract terms) for, respectively, its customers or suppliers. A monopolist can harm its customers by raising prices or restricting output; a monopsonist can harm its suppliers by lowering what it pays and restricting purchases.

In the case of markets for labor, the monopsony model is usually used. ${ }^{161}$ Monopsony theory might explain why, for instance, Uber's rates have been going down and why the rates of other companies once they consolidate their position - are likely to go down. When it has signed up enough drivers, Uber can afford to increase the fee that it charges drivers or respectively, decrease the portion of what drivers get. The same holds for other sharing economy platforms which charge fees for matching customers and suppliers. Price discrimination - possible via online tools - can increase Uber's ability to extract even more surplus from its drivers by allowing it to segment among those most dependent on the platform and those most likely to walk away. Such price discrimination can lead to a further reduction of fees for some drivers. Applying Article 102 TFEU or its national equivalents could be a

\footnotetext{
160 Joliet, Monopolization and Abuse of Dominant Position: A Comparative Study of the American and European Approaches to the Control of Economic Power (Nijhoff 1970); also Akman, 'Searching for the Long-Lost Soul of Article 82EC' (2009) 29 (2) Oxford Journal of Legal Studies, 267.

${ }^{161}$ Labor purchasing is the classic example of a monopsony used in economics textbooks. See Manning op.cit. supra note 1.
} 
useful tool of intervention in cases in which powerful online platforms impose unfair prices or terms on their suppliers - in this case, the self-employed.

However, there are some barriers to applying Article 102 in such cases and these barriers have nothing to do with the self-employed. From a positive law perspective the doctrine of exploitative abuse has been affirmed in a number of Commission decisions ${ }^{162}$ and Court judgments ${ }^{163}$. Thus, there can be no question that EU competition law aims to protect the victims of monopolists and monopsonists ${ }^{164}$ and can be used in the context of unfair trading terms imposed by one contractual partner on another.

From a normative perspective, however, the doctrine remains a controversial one. ${ }^{165}$ Firstly, the doctrine is difficult to reconcile with the more economic approach pursued by the European Commission. ${ }^{166}$ Although in principle, economists are sympathetic about arguments related to efficiency losses, their concerns are primarily related to enforcement errors (type I versus type II), ${ }^{167}$ inherent in establishing this type of abuse.. Over-deterrence is considered especially problematic as it threatens to 'chill competition' and scare companies away from potentially efficient commercial practices. The prevailing viewpoint is that in order to avoid chilling competition, a sophisticated economic analysis is necessary; however, this type of analysis is difficult, expensive and requires a lot of data that authorities and plaintiffs often do not have. Economists caution - with good reason - that authorities need to be rigorous in testing exploitative abuse claims for fear of unmeritorious claims. ${ }^{168}$ This is one reason which explains authorities' reserved stance toward exploitative practices. This mismatch between the normative preferences of enforcers and the positive law has led to a dearth of case law and decision practice. ${ }^{169}$ The Commission in recent years has avoided excessive pricing cases with the notable exception of the telecommunications markets. ${ }^{170}$

\footnotetext{
162 See Commission Decision No IV/28.851- General Motors Continental; Commission Decision IV/26699 - Chiquita [1975] OJ 95/1-20; Commission Decision IV/30.615 - British Leyland, OJ L [1984] 207/11. More recent decisions include Case COMP/C-1/36.915 - Deutsche Post AG - Interception of cross-border mail [2001]; Case COMP D3/34493 - DSD (Commission Decision of 20 April 2001) OJ L [2001] 166/1 Case COMP/C-2/37.761; Euromax v/IMAX Decision of 25.03.2004; Case COMP/A.36.568/D3 - Scandlines Sverige AB v Port of Helsingborg. ${ }^{163}$ Case 26-75 General Motors Continental NV v Commission of the European Communities [1975] ECLI:EU:C:1975:150; Case C- 27/76 United Brands Company and United Brands Continentaal BV v Commission of the European Communities [1978] ECLI:EU:C:1978:22; Case 226/84 British Leyland Public Limited Company v Commission of the European Communities [1986] ECLI:EU:C:1986:421; Case 30/87 Bodson v Pompes Funèbres des Régions Libérées [1988] ECLI:EU:C:1988:225; Case 395/87 Ministère Public v Jean-Louis Tournier [1989] ECLI:EU:C:1989:319 (SACEM I); Joined Cases 110/88, 241/88 and 242/88 François Lucazeau v SACEM and others [1989] ECLI:EU:C:1989:326 (SACEM II); Case 66/86 Ahmed Saeed Flugreisen and Siver Line Reisebüro GmbH v Zentrale zur Bekämpfung unlauteren Wettbewerbs e.V. [1989] ECLI:EU:C:1989:140; Case 298/83 Comité des industries cinématographique des Communautés européennes (CICCE) [1985] ECLI:EU:C:1985:150; Case C-323/93 Société Civile Agricole du Centre d'Insémination de la Crespelle v Coopérative d'Elevage et d'Insémination Artificielle du Département de la Mayenne [1994] ECLI:EU:C:1994:368, (Crespelle); Case C-242/95 G-T Link A/S v De Danske Statsbaner (DSB) [1997] ECLI:EU:C:1997:376 ; Case C-340/99 TNT Traco SpA v Poste Italiane SpA [2001] ECLI:EU:C:2001:281; Case C-385/07 P Der Grüne Punkt - Duales System Deutschland GmbH v Commission of the European Communities [2009] ECLI:EU:C:2009:456.

${ }^{164}$ For an early argument to this effect, see Joliet op. cit. supra note 161 at 243. On monopsony and the application of the EU competition rules to it see Daskalova op. cit. supra note 149; More generally on monopsony, see Blair and Harrison, Monopsony in Law and Economics ( $1^{\text {st }}$ edn, CUP 2010); specifically on the economics of monopsony in labor markets, see Manning op.cit. supra note 1.

${ }^{165}$ Konkurrensverket (Swedish Competition Authority), 'The Pros and Cons of High Prices' (Conference Proceedings 2007).

${ }^{166}$ See EAGCP, “An Economic Approach to Article 82" (Report, 2005)

${ }^{167}$ Type I error stands for 'under-enforcement' and type II stands for 'over-enforcement'. The prevailing opinion is that under-enforcement is preferable to over-enforcement because over-enforcement tends to chill competition.

${ }^{168}$ See Lyons, 'The Paradox of the Exclusion of Exploitative Abuse' (2007) CCP Working Paper 08-1, 1.

169 Jones and Sufrin, EU Competition Law: Texts, Cases, and Materials (6th edn, OUP 2016), (2016), 573; Svetlicinii and Botta, 'Article 102 TFEU As A Tool for Market Regulation: "Excessive Enforcement" Against "Excessive Prices" in the New EU Member States and Candidate Countries' (2012) 8 (3) European Competition Journal, 473, 473. However, Svetlicinii and Botta note that the sentiment toward exploitative abuse is not shared by enforcers in the new Member States.

${ }^{170}$ Jones and Sufrin, op. cit. supra note 169 at 567.
} 
Arguably, the tides are changing but perhaps not in the direction most beneficial to self-employed. In a speech delivered in November 2016, Commissioner for competition Margareth Vestager has argued for more enforcement of the competition rules on abuse of dominance in cases involving consumers. The prioritization of consumer interests over producer interests has been a defining characteristic of EU competition law following the 'modernization' in 2014. Although the Courts have confirmed that competition law is not only about the protection of consumer welfare, ${ }^{171}$ the Commission still very much prioritizes infringements that are likely to impact consumers rather than producers. ${ }^{172}$ In this sense, Europe has very much departed from its 'producerist' past and prioritizes the interests of consumers over the interest of producers, ${ }^{173}$ among which we find workers and independents.

From a pragmatic point of view, an additional limitations to the usefulness of Article 102 TFEU is the underdeveloped methodology for testing unfairness. Although it is accepted that companies in a dominant position can be found guilty of a breach of Article 102 TFEU when acting unfairly, there is little agreement on the methodology for determining unfairness. The Court has given some indications about when a price imposed by a dominant seller is to be considered excessively high, ${ }^{174}$ and even fewer indications as to when a price imposed by a dominant purchaser is to be considered excessively low. ${ }^{175}$

Finally, the doctrine under Article 102 TFEU only covers dominant companies. The markets in question are rapidly developing and competition is growing. Exploitation in the context of superior bargaining power is possible - as we know from the debate on supermarkets, but it cannot be accommodated within the dominance doctrine - simply because not one company will be in a position of dominance. This brings us back to the original problem - that there is no legal solution to the unfair terms in the context of $\mathrm{B} 2 \mathrm{~B}$ relations where there is a serious imbalance in bargaining powers. So the answer is: competition law may help, but it does not solve all the problems related to unequal bargaining power.

\section{Conclusions}

Part of the enthusiasm for companies like Uber stems from a deep dislike of cartels and a deep dislike of limitation of economic choices and opportunities for participation in the economy. The development of the sharing economy is often framed in terms of increased competition and improved consumer choice. Uber is sometimes seen as the revolutionary who dares to break into markets dominated by law-backed cartels of taxi drivers, thus delivering benefits to consumers but also opening labor possibilities for independents. Yet one should not be blinded to the possibility that today's revolutionaries will be the merciless dictators of tomorrow. One-sided enforcement targeting 'supplier

\footnotetext{
171 The Court ruled to this effect in Joined Cases C-501/06 P, C-513/06 P, C-515/06 P and C-519/06 P GlaxoSmithKline v Commission [2009] ECLI:EU:C:2009:610; See the discussion in Daskalova, 'Consumer Welfare in EU Competition Law: What Is It (Not) About?' (2015) 11(1) Competition Law Review, 133.

172 Vestager, 'Protecting consumers from exploitation' (Speech, Chillin' Competition Conference, Brussels, 21 November 2016) < http://ec.europa.eu/commission/2014-2019/vestager/announcements/protecting-consumers-exploitation en >; Vestager, 'Setting priorities in antitrust' (Speech, GCLC, Brussels, 1 February 2016) <http://ec.europa.eu/commission/20142019/vestager/announcements/setting-priorities-antitrust en >

${ }^{173}$ Whitman, 'Consumerism Versus Producerism: A Study in Comparative Law' (2007) 117(3) The Yale Law Journal, 340.

${ }^{174}$ Case C- 27/76 United Brands Company and United Brands Continentaal BV v Commission of the European Communities [1978] ECLI:EU:C:1978:22, [250-253].

${ }^{175}$ See Case 298/83 Comité des industries cinématographique des Communautés européennes (CICCE) [1985] ECLI:EU:C:1985:150; Some indications are available in European Commission, "Quantifying harm in actions for damages based on breaches of Article 101 or 102 of the Treaty on the Functioning of the European Union" (Practical Guide) SWD(2013) 205, 42-43.
} 
cartels' of self-employed while not taking steps to limit possibilities for abuses of power by platforms and large purchasers of services that self-employed provide is questionable - if not necessarily from a consumer welfare perspective, then surely from a social justice perspective.

This paper started with the problem of applying the same rules that hold for companies - the competition rules - to the 'new self-employed'. It has provided evidence to show that the category of 'self-employed' is a wildly heterogeneous one. Within that group, we can distinguish between traditional self-employed and the 'new self-employed' who are characterized by the absence of personnel, and lack of entrepreneurial characteristics. The group is home to both wealthy service providers, entrepreneurs, and highly vulnerable service-providers. The labor laws and the right to collective bargaining do not apply to this group of people unless it can be shown that they fulfill the traditional tests for 'worker'. Yet, as argued on the basis of the EU law definition of a worker - this legal category is not likely to cover many of the new self-employed, and especially those engaged in the 'on-demand' economy. Rather than providing an effective exception, the judgment in FNV Kiem confirmed the traditional approach to defining who is a 'worker' by holding that bogus self-employed should fulfill the criteria for 'worker'. As a result, the concept of 'worker' remained narrowly construed. At the same time, the concept of 'undertaking' under the competition rules remains a broad one thus making competition law applicable to all self-employed, including the most precarious one.

Looking for an exception to the collective bargaining prohibition within the competition rules has proved to be a difficult task, so then the question was posed: what other possibilities are there to address this problem? Analyzing the problem with the help of regulatory quadrants revealed various opportunities for addressing the issue. A preliminary analysis shows that a number of tools - private and public, ex ante and ex post, are available to address the issue. What the optimal mix of tools for solving the problem of unequal bargaining power between self-employed and their contract partners is remains a question for further research. In an improved regulatory regime, competition law can certainly play a meaningful role. Firstly, it can guard that competition among platforms remains robust so that self-employed have real choice of whom they can contract with. Secondly, competition law can guard that matchmakers do not abuse their power vis-à-vis service providers. Of course, the competition law doctrine as it stands also suffers from its own limitations. Nonetheless, it is important to consider the potential of competition law - as a form of generally applicable regulation - to address problems for those most vulnerable service-providers who will never - despite revisions of the concept of worker - be protected under the labor laws.

It is conceivable that a combination of instruments - such as codes of conduct, sector-specific rules or rules targeting particular business models - might solve the problem for some of the new selfemployed. Private strategies such as forming cooperatives or partnerships of self-employed service providers could also help independents improve their bargaining strength. Still, the concern remains for the most disenfranchised independents who are incapable of organizing and who do not fit within classes of workers or groups protected by specific regulation. This is where competition law should be of help, not of harm. 